
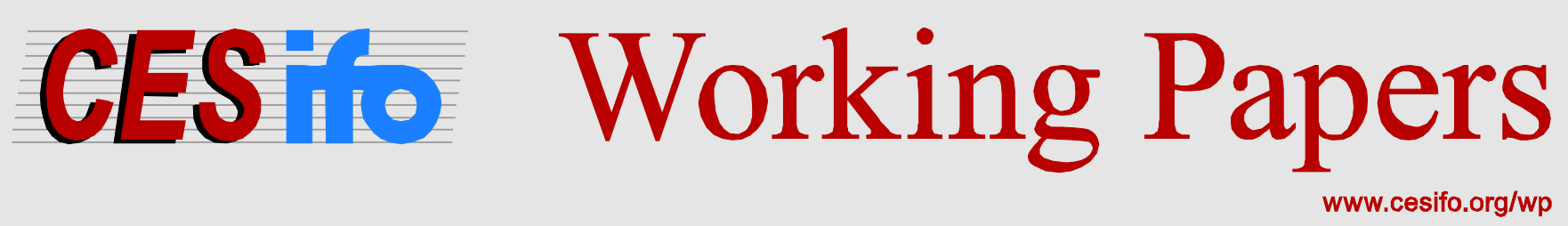

\title{
Analysing the Determinants of Credit Risk for General Insurance Firms in the UK
}

\author{
Guglielmo Maria Caporale \\ Mario Cerrato \\ Xuan Zhang
}

\author{
CESIFO WORKING PAPER NO. 5971 \\ CATEgory 7: Monetary POLICY AND InTERnational FinanCE \\ JUNE 2016
}

An electronic version of the paper may be downloaded

- from the SSRN website:

- from the RePEc website:

- from the CESifo website:

www.SSRN.com

www.RePEc.org

www.CESifo-group.org/wp 


\title{
Analysing the Determinants of Credit Risk for General Insurance Firms in the UK
}

\begin{abstract}
This paper estimates a reduced-form model to assess the credit risk of General Insurance (GI) non-life firms in the UK. Compared to earlier studies, it uses a much larger sample including 30 years of data for 515 firms, and also considers a much wider set of possible determinants of credit risk. The empirical results suggest that macroeconomic and firm-specific factors both play important roles. Other key findings are the following: credit risk varies across firms depending on their business lines; there is default clustering in the GI industry; different reinsurance levels also affect the credit risk of insurance firms. The implications of these findings for regulators of GI firms under the coming Solvency II are discussed.
\end{abstract}

JEL-Codes: G220, C580.

Keywords: insolvent, doubly stochastic, insurance, reinsurance.

\author{
Guglielmo Maria Caporale* \\ Department of Economics and Finance \\ Brunel University London \\ United Kingdom - UB8 3PH, London \\ Guglielmo-Maria.Caporale@brunel.ac.uk
}

\author{
Mario Cerrato \\ University of Glasgow \\ United Kingdom - G12 8YY, Glasgow \\ Mario.Cerrato@glasgow.ac.uk
}

\author{
Xuan Zhang \\ University of Glasgow \\ United Kingdom - G12 8QQ, Glasgow \\ x.zhang.2@research.gla.ac.uk
}

*corresponding author

June 2016

We are grateful to Standard \& Poor's and the Bank of England for data support. We have benefited from comments from Papachristou Dimitris, Claus Stefan, Khaleghy Jennifer, Winter Richard, David Simmons, Nylesh Shah and others from the General Insurance Division of the Bank of England. 


\section{Introduction}

The UK’s non-life insurance industry is worth £60bn and is the largest in Europe and the third largest in the world (after the US and Japan). It comprises more than 300 active firms (both domestically- and foreign-owned); ${ }^{1}$ in addition, 94 Lloyds's syndicates also underwrite non-life business (Lloyd's Annual Report 2014). In total, it currently generates approximately £48.217bn in gross written premium income (International Underwriting Association, 2015).

Compared to the banking sector, the insurance industry is relatively stable and less subject to risk: unlike banks, insurers do not accept deposits from customers, and therefore they do not face the risk of a sudden shortage in liquidity that may cause bank runs; also, they often hold more long-term than short-term liabilities. Bell and Keller (2009) find that insurers are less interconnected than banks and there is less contagion among them. However, Janina and Gregor (2015) argue that insurance firms are becoming more similar to banks and contribute to the systemic risk of the financial sector. Further, a study by the Geneva Association (2010) indicates that the insurance industry increases systemic risk if insurers engage heavily in trading derivatives off the balance sheet or mismanage short-term financing activities.

It is very difficult to access data on the credit risk of insurance firms because very few have become "insolvent" - the majority choose instead to transfer their business to other insurance firms or just stop underwriting new business. As an alternative, third-party rating agencies may provide a good overview of their financial condition. The main problem with external rating agencies is that not all insurance firms are rated and the ratings normally stay the same for many years. Also, different rating agencies such as A M Best, Standard \& Poor's, Moody's and Fitch have different rating methodologies and labelling systems.

Under Solvency II, credit risk is defined as the risk of loss (or of adverse change) in the financial situation of a company which results from fluctuations in the credit standing of issuers of securities, counterparties and any debtors to which a Solvency II undertaking is exposed, in the form of counterparty default risk, spread risk, or market risk concentration. ${ }^{2}$

In this paper, we assume that the credit risk of insurance firms is made up of three components. The first is the credit quality of their investment portfolio, whose performance we measure using investment returns. The second is the counter-party risk through

\footnotetext{
${ }^{1}$ In addition, more than 500 non-life insurance firms that are not regulated by the UK government are licensed by the European Economic Area to conduct business in the UK (Financial Services Authority, 2013).

${ }^{2}$ Art. 13(32) of the Solvency II Directive
} 
reinsurance activity and the purchasing of derivative contracts. A high reinsurance ratio and holding derivative contracts increase the credit risk exposure of firms. The reinsurance ratio and a dummy variable for the use of derivative contracts are therefore used in our study to capture this second component. The third is the direct default risk of insurers when their liabilities are less than their assets and therefore they might become insolvent. The financial health of firms is measured here using the leverage, profitability, solvency and liquidity ratios. Size, growth and claims volatility are also taken into account.

We consider different exit situations for firms, including insolvency and transferring business to a third party. Ours is the first study to use a very large dataset consisting of 30 years of data for 515 firms to analyse the credit risk of General Insurance (GI) firms in the UK. We show that other risk factors (macroeconomic and firm-specific factors), in addition to the standard ones considered by the literature (i.e. interest rate, whole sale price change, credit supply change, usage of financial derivatives and combined ratios) affect insurers' insolvency. When assessing their profitability, we take into account profit from both the traditional underwriting business and investment activities. We estimate both the individual probability of default (PD) for all available firms and the joint one using pair correlations. Ours is the first paper to analyse the systemic risk of insurance firms in the UK on the basis of their individual PD. Our results show high dependence between insurance firms when their individual PDs are high; this suggests that the joint probability of default is higher during distress times. Finally, we examine the relationship between reinsurance and change in the credit risk of insurance firms. Previous studies show that primary insurers can benefit from reinsurance contracts in many ways (e.g. they can hedge against risk, and hold more capital to underwrite new business). We show that reinsurers may also benefit from reinsurance activities by reducing their credit risk.

The layout of the paper is as follows. Section 2 briefly reviews the relevant literature. Section 3 discusses the data and the various determinants of risk considered. Section 4 outlines the modelling approach. Section 5 discusses the empirical results. Section 6 summarises the main findings and offers some concluding remarks.

\section{Literature Review}

Insurance firms play a very important role in the economy. Most studies (Carmichael, Pomerleano, 2002, Das et al., 2003, Lee, 2013 and Lee and Chang, 2015) suggests that they 
can enhance financial stability by transferring risk to multiple parties through insurance and reinsurance activities. Rothstein (2011) shows that a healthy and well-developed insurance industry will improve the stability of financial markets. In addition, insurance firms protect individuals and corporations from losses arising from natural disasters such as floods etc. (Adams et al., 2005; Faure and Heine, 2011; Kugler and Ofoghi, 2005; Ward and Zurbruegg, 2000).

The insurance industry is thought to be less exposed to turbulence in financial markets than other industries such as banking. There are several possible reasons for this difference. Harrington (2009) argues that insurance firms have to comply with more rigorous capital requirements than other financial institutions, and as a result credit events in the insurance industry have a small effect on the stability of the financial system as a whole. Das et al. (2003) suggest that the insurance industry is more stable because insurers do not suffer from bank runs, and the cancellation process for insurance policies takes longer than closing a bank account. Furthermore, because of larger premia, policy holders would suffer a loss if the policy were cancelled.

However, recent developments have made the insurance industry less stable; in particular, the fast growth of financial derivatives has meant that insurance firms have become more engaged with banks (through trading financial derivatives and other investment activities). Schinasi (2006) and Rule (2001) find that more insurance firms are buying credit default swaps to hedge their credit risk and using alternative risk transfer (ART) tools such as catastrophe bonds to transfer the catastrophe risk to other investors. Also, investment in assetbacked securities has increased. As a result, as pointed out by Baluch et al. (2011), insurance firms have become more vulnerable during crises. This is also shown by studies such as those by Das et al., (2003), who find that linkages through reinsurance activities may cause several primary insurance firms to fail at the same time, and by Acharya et al. (2015), who suggest that large insurance firms are more likely to invest in high-risk assets because they are correlated with different financial institutions. One of the contributions of this paper is to assess the vulnerability of the UK insurance industry; to the best of our knowledge, this is the first time this issue is addressed in the case of the UK.

The linkage between insurance firms and banking crises should not be ignored, since insurance firms play a crucial role in financial markets. For example, Main (1982) shows that banks can avoid some bad debts by working with them. This is because the information on 
obligors provided by insurance firms helps banks to understand individual and corporate risk exposures better. In addition, by mitigating the losses during natural disasters, insurance firms help to reduce the probability of default of some investors (policy holders, both individual and corporate) who, sometimes, are the same obligors as those of banks (C.-C. Lee et al, 2016). Lehmann and Hofmann (2010) show that banks are more likely to transfer part or all of their risks to other financial sectors to avoid high correlation between assets that may lead to a higher default probability. Trichet (2005) shows that the insurance and banking industries are linked by ownership and the associations of credit exposure. As a result, insurance firms are playing a central role in financial markets and this may directly affect banks.

One of the most recent papers on the UK non-life insurance industry is by Shiu (2011), who uses data from 1985 to 2002 to investigate the relationship between reinsurance and capital structure. He shows that insurers with higher leverage tend to purchase more reinsurance, and those with higher reinsurance dependence tend to have a higher level of debt. Using the same database, Shiu (2007) shows that an insurer's size, liquidity, interest rate risk exposure, line of business concentration and organizational form are important factors associated with the decision to employ financial derivatives. Adam et al. (2003) explore the determinants of credit ratings in the UK insurance industry analysing a sample of 65 firms over the period from 1993 to 1997. They find that mutual insurers are generally given higher ratings than non-mutual ones. Also, liquidity and profitability have a significant positive effect on ratings.

Most previous studies on credit risk focused on banking crises. For example, early warning systems are well developed for banks (e.g., Kaminsky and Reinhart, 1999; Borio and Drehmann, 2009; Drehmann and Juselius, 2014; Demirgüç-Kunt and Detragiache, 1998; Barell et al., 2010 and Schularick and Taylor, 2012). Given the fact that insurance firms play a central role in financial markets and are becoming more engaged with banks, analysing their credit risk is clearly important. In the present study, we employ a reduced-form model to assess it in the case of the UK.

\section{Data and Covariates}

Firm-specific variables are collected from SynThesys Non-Life. ${ }^{3}$ This consists of FSA data (now regulated under the Prudential Regulation Authority, Bank of England) of non-life

\footnotetext{
${ }^{3}$ From Standard \& Poor's
} 
annual return regulatory data. This database allows quick access to FSA return data for the current year and past years back to 1985 . Over 400 companies are covered by the current SynThesys Non-Life system and the data include statements of solvency, components of capital resources, statements of net assets, calculations of capital requirement, analysis of admissible assets, liabilities, the profit and loss account, analysis of derivative contracts, summary of business carried on, technical account, analysis of premiums, analysis of claims, analysis of expenses and analysis of technical provisions etc. Also, there are approximately 180 ratios currently included, with all the underlying calculations being done by SynThesys.

Since most general insurance firms are small and non-public, there is no specific default list. Further, in the UK market, instead of becoming insolvent, most general insurance firms go into 'Run-Off' (i.e. stop underwriting new business and wait for their financial condition to improve or transfer their business to others). All the credit events in our paper have been collected by hand from Appendix D: Company Changes, Transfers, Mergers of SynThesys Non-Life UserGuide version $10.1^{4}, P w C$ - Insurance insolvency ${ }^{5}$ and Financial Services Compensation Scheme ${ }^{6}$, and the final list has been further discussed with technical specialists and senior supervisors from the Insurance Division at the Bank of England. Macroeconomic data have been obtained from the World Bank. Therefore, ours is a unique dataset for the insurance industry in the UK.

Before analysing the data, we remove firms without at least one-year balance data for all the variables. This is because these firms cannot be used to calibrate the model. We also remove firms for reasons such as merger \& acquisitions, insolvency or simply running off and disappearing. More discussion of the different types of firms' exit can be found in the model section. In the end, we are left with 363 firms with 14 firm-specific variables and 6 macroeconomic variables in our dataset spanning from 1986 to 2014. These include 35 firms that became insolvent during that period and 45 firms that exited owing to other reasons such as transferring their business to other firms.

To lessen the effect of outliers, we use cap the reinsurance ratio and leverage ratio at the 95 percentile value and remove the lower 5 percentile value. Also we cap the liquidity ratio, profitability ratio, growth premium written change, claim change and excess capital ratio at the 99 percentile value and remove the lower 1 percentile value. The summary statistics and

\footnotetext{
${ }^{4}$ Updated on November 2014

${ }^{5}$ http://www.pwc.co.uk/services/business-recovery/insights/insurance-insolvency-case-updates-pwc-uk.html

${ }^{6}$ http://www.fscs.org.uk/what-we-cover/products/insurance/insurance-insolvencies/
} 
correlation matrix of firm-specific and macroeconomic variables respectively are reported in Table 1, 2 and 3.

\subsection{Covariates}

Following the literature, ${ }^{7}$ we choose the following firm-specific variables: leverage (Net Technical Provisions /Adjust Liquid Assets, SynThesys Appendix K: Ratio Definitions R12), profitability (underwriting profit to Total Assets), growth (the change in the natural logarithm of total admissible assets), firm size (the natural logarithm of total admitted assets), reinsurance (the ratio of Reinsurance Premiums Ceded to Gross Premium written), claims change (the change in net claims incurred), capital (the change in excess capital resources to cover general business CRR), liquidity (Cash/Total Asset: the ratio of the sum of cash and short-term investments to total assets), gross premium written (the annual change in gross premium written), combined ratio (Incurred Claims + Management Expense) / Gross Premium Written), Line-of-Business Concentration (Herfindahl index), organizational form (mutual or non-mutual firm) and a derivative dummy variable (Derivative dummy defined based on SynThesys form 17, i.e. whether the sum of form 17 is zero or not). In addition, we also include UK macroeconomic variables, namely GDP growth, the change in the wholesale price index $(2010=100)$, the change in foreign direct investment, net inflows, the real interest rate, the real effective exchange rate index $(2010=100)$ and the change in the credit provided by financial institutions (\% of GDP) from the World Bank.

\section{Leverage}

Higher leverage may have an adverse effect on insurance firms by affecting their underwriting performance and making an insurer’s capital more vulnerable to economic shocks. Further, Adams et al. (2003) find that insurers with lower financial leverage are more likely to be given a higher credit rating. Previous studies such as Brotman (1989) and Pottier (1997, 1998) also report a negative relationship between financial leverage and the capital structure of insurance firms.

\section{Profitability}

Profitability indicates the ability of insurance firms to generate a surplus to develop their current business and generate new business. A higher profitability ratio means that the

\footnotetext{
${ }^{7}$ Brotman (1989), Adams (1995), Pottier (1997, 1998), Adams et al. (2003) and Shiu (2011) etc.
} 
insurance firm can manage expenses effectively and set competitive premium rates. Titman and Wessels (1988) and Frank and Goyal (2009) also suggest that highly profitable firms have a lower debt ratio and hence a lower credit risk.

\section{Firm Growth}

Normally, a positive growth ratio signals a good financial condition for a firm. But for issuers with significant new business growth could be achieved by poor underwriting standards and mispricing strategy (Adams et al., 2003). Borde et al. (1994) and Pottier (1997) find that this will lead to greater uncertainty about the capital reserve risk for insurance firms. Further, Frank and Goyal (2009) conclude that firms with a high growth ratio face more debt-related agency issues and higher associated cost.

\section{Firm Size}

Prior studies such as Bouzouita and Young (1998) find that large insurers are less likely to become insolvent; they normally benefit from economies of scale, and given their sizeable market shares and higher ratings have lower financing costs than small insurers (Adams et al., 2003).

\section{Reinsurance}

Berger et al. (1992) point out that there are two types of traditional reinsurance activities involving a direct insurer ceding all or part of its assumed underwritings to another insurance company. Insurance firm transfer part of their risk to third parties by reinsurance, which result in lower uncertainty concerning their future losses and enables them to reduce their capital reserves. Adams (1996) suggests that reinsurance improves the ability of the primary insurer to survive an external economic shock. On the other hand, the financial health of a heavily reinsured firm will be adversely affected by the insolvency of reinsurance firms.

\section{Claims Growth ${ }^{8}$}

In the insurance industry, incurred claims are the amount of outstanding liabilities for policies over a given valuation period. A significant increase in net claims may generate liquidity risk for an insurer, which will eventually become insolvent if it cannot raise enough capital.

\footnotetext{
${ }^{8}$ Difference of annual incurred claims
} 


\section{Capital}

When measuring the default risk of insurance firms, it is natural to include the Excess (deficiency) of capital resources to cover general business CRR (Capital Requirements Regulation). Insurance firms should hold enough capital to cover the policies they underwrite.

\section{Liquidity}

We use the cash ratio as a measure of a firm's liquidity. For insurance firms, a high liquidity ratio indicates good claim-paying ability. Previous studies such as Carson and Scott (1997) and Bouzouita and Young (1998) show a negative correlation between the liquidity risk and the credit rating of insurance firms.

\section{Gross Premium Written Growth}

Generally speaking, an increase in gross premia written ${ }^{9}$ indicates that the insurance firm is in a good financial condition. Incorporating this variable into the model will automatically exclude 'run-off' firms from the sample; these are very common in the insurance industry (insurance firms can stop underwriting business but still exist for many years).

\section{Derivative Dummy}

Shiu (2011) notes that insurers use derivatives to hedge risk, which may also increase their exposure to counterparty risk. Following his study, we obtain label 1 for a derivative user by looking for nonzero values from Form 17 of the PRA returns.

\section{Organizational Form}

Adams (1995) argued that the organizational form can partly affect the decision-making of insurance firms. A mutual insurance firm is an organization that supplies insurance services, and that is owned by its customers, or members, which means that there are no shareholders to pay dividends to or to be accountable to. Such a firm can concentrate entirely on delivering products and services that best meet the needs of its customers. In our analysis we separate mutual and non-mutual firms.

\footnotetext{
${ }^{9}$ These are the total premia written, which include both direct and assumed premia written, before any reinsurance.
} 


\section{Combined Ratio}

We include the combined ratio defined as Incurred Claims + Management Expense) / Gross Premium Written) in the model to capture any mispricing by insurers.

\section{Line-of-Business Concentration}

Insurers with a high line-of-business concentration may have a higher earning risk. We follow Shiu (2011) in using the Herfindahl index to proxy the line-of-business concentration (a higher number indicates a lower level of business mix, the max value is 1 ):

$$
H=\sum_{i=1}^{N} S_{i}^{2}
$$

where $s_{i}$ is the premium written for one business line / [Gross Premium Written (Total Primary direct \& fac. Business) - Gross Premium Written (Total Treaty reinsurance accepted business)].

\section{GDP Growth}

The annual percentage growth rate of GDP at market prices is calculated using values in 2005 US dollars.

Change of Wholesale Price Index (2010=100)

The wholesale price index includes a mix of agricultural and industrial goods at various stages of production and distribution, including import duties.

Change of Foreign Direct Investment, Net Inflows

Foreign Direct Investment is defined as direct investment equity flows in the reporting economy. It is the sum of equity capital, reinvestment of earnings, and other capital. Direct investment is a category of cross-border investment associated with a resident in one economy having control or a significant degree of influence on the management of an enterprise that is resident in another economy. ${ }^{10}$

\footnotetext{
${ }^{10}$ According to the World Bank, ownership of 10 percent or more of the ordinary shares of voting stock is the criterion for determining the existence of a direct investment relationship.
} 


\section{Real Interest Rate}

The real interest rate is the lending interest rate adjusted for inflation as measured by the GDP deflator. The terms and conditions attached to lending rates differ by country, however, which limits their comparability.

Real Effective Exchange Rate Index (2010=100)

The real effective exchange rate is the nominal effective exchange rate (which measures the value of a currency against a weighted average of several foreign currencies) divided by a price deflator or index of costs.

Change of Credit provided by Financial Institutions (\% of GDP)

Domestic credit provided by the financial sector includes all credit to various sectors on a gross basis, with the exception of credit to the central government, which is net. The financial sector includes monetary authorities and deposit money banks, as well as other financial corporations when data are available (including corporations that do not accept transferable deposits but incur such liabilities as time and savings deposits). ${ }^{11}$

\subsection{Summary Statistics}

As already pointed out, the insurance industry is relatively more stable than other industries. This is confirmed by Table 1, which shows that the standard deviation (Std) of underwriting profitability (PT) and investment return (InvR) is very small. ${ }^{12}$

\footnotetext{
${ }^{11}$ Examples of other financial corporations are finance and leasing companies, money lenders, insurance corporations, pension funds, and foreign exchange companies.

${ }^{12}$ Compared to banks, insurers do not face the risk of a'bank run' and claiming payments from them normally takes longer than withdrawing cash from banks.
} 


\section{Table 1}

Summary Statistics - Full Sample

\begin{tabular}{lrrrrr}
\hline & Max & \multicolumn{1}{l}{ Min } & Median & Average & Std \\
\hline PT & 0.31 & -0.30 & -0.01 & -0.01 & 0.06 \\
Lev & 1.36 & 0.02 & 0.60 & 0.59 & 0.32 \\
Size & 17.83 & 1.29 & 11.31 & 11.34 & 2.18 \\
CA & 0.99 & 0.00 & 0.11 & 0.21 & 0.23 \\
GPW \% & 11.21 & -3.50 & 0.03 & 0.08 & 0.93 \\
Rein & 1.00 & 0.00 & 0.24 & 0.32 & 0.30 \\
Claim \% & 25.89 & -6.89 & 0.03 & 0.23 & 1.96 \\
Growth & 6.47 & -9.45 & 0.01 & 0.02 & 0.41 \\
Excess \% & 8.74 & -4.22 & 0.05 & 0.17 & 0.96 \\
Combined & 24.12 & -1.00 & 0.44 & 1.03 & 2.71 \\
InvR & 0.11 & -0.04 & 0.03 & 0.03 & 0.02 \\
H-Index & 1.00 & 0.00 & 0.76 & 0.71 & 0.28 \\
\hline
\end{tabular}

Table 1. Maximum, minimum, median, average and standard deviation of firm-specific variables which including underwriting profit, leverage ratio, firm size, cash ratio, change of gross premium written, reinsurance ratio, change of incurred claims, growth ratio, change of excess capital, combined ratio, investment return and Herfindahl index of the whole industry.

\section{Table 2}

\section{Summary Statistics - Default Firms}

\begin{tabular}{lrrrrr}
\hline & \multicolumn{1}{l}{ Max } & \multicolumn{1}{l}{ Min } & Median & Average & Std \\
\hline PT & 0.29 & -0.24 & -0.02 & -0.03 & 0.06 \\
Lev & 1.35 & 0.02 & 0.76 & 0.73 & 0.30 \\
Size & 15.25 & 5.82 & 11.46 & 11.33 & 1.66 \\
CA & 0.97 & 0.00 & 0.12 & 0.19 & 0.20 \\
GPW \% & 8.03 & -3.39 & -0.07 & -0.10 & 0.95 \\
Rein & 1.00 & 0.00 & 0.44 & 0.45 & 0.27 \\
Claim \% & 25.07 & -6.04 & 0.01 & 0.09 & 1.76 \\
Growth & 1.59 & -1.42 & -0.02 & -0.01 & 0.28 \\
Excess \% & 6.97 & -3.43 & 0.01 & 0.09 & 1.01 \\
Combined & 24.06 & -0.98 & 0.48 & 1.75 & 3.47 \\
InvR & 0.09 & -0.03 & 0.02 & 0.02 & 0.02 \\
H-Index & 1.00 & 0.19 & 0.78 & 0.73 & 0.26 \\
\hline
\end{tabular}

Table 2. Maximum, minimum, median, average and standard deviation of firm-specific variables which including underwriting profit, leverage ratio, firm size, cash ratio, change of gross premium written, reinsurance ratio, change of incurred claims, growth ratio, change of excess capital, combined ratio, investment return and Herfindahl index of default firms. 
Insurance firms, on average, have a higher investment profit than the traditional underwriting profit. ${ }^{13}$ This could be driven by derivative trading (Schinasi (2006) and Rule (2001)). On average, general insurance firms in the UK are well capitalised, the reason being that they have to comply with more rigorous capital requirements than financial institutions (Harrington 2009). The size of firms changes a lot over the sample period that we are considering, suggesting that, although the industry as a whole is relatively stable, many insurance firms transfer their business to others before they become insolvent. ${ }^{14}$ This is also why we consider the transfer of the business to other companies as a possible form of exit. The high volatility of the combined ratio (Combined) could be due to mispricing problem. The Herfindahl index is 0.71 on average with a small standard deviation. This further supports the view that insurance firms are stable and their business is not very diverse.

Table 2 show that, compared to the full sample, on average default firms have negative underwriting profit (PT) and gross premium written change (GPW \%). They have low cash ratio (CA), small incurred claim increase (Claim \%), small excess capital increase (Excess \%) and low investment return (InvR). This may indicate that they lose money from their main business and their investment performance is not as good as in the case of other firms. They are relatively small size firms with slow business growth, and holding less capital makes them more vulnerable. They also have higher leverage, reinsurance ratio, combined ratio and Herfindahl index (H-index), which suggests that they are more exposed to interest risk, credit risk and market risk. Overall, the evidence in Table 2 confirms the previous findings of the literature (see, e.g., Adams et al., 2003 and Shiu, 2011).

\footnotetext{
${ }^{13}$ Investing in high-risk portfolios may yield higher returns than the normal underwriting business.

${ }^{14}$ To protect the interests of policy-holders, insurance firms are more likely to stop writing new business or transfer their business to other firms rather than becoming insolvent.
} 
Table 3

Correlation Matrix of Firm-specific Variables

\begin{tabular}{|c|c|c|c|c|c|c|c|c|c|c|c|c|}
\hline & $\mathrm{PT}$ & Lev & Size & $\mathrm{CA}$ & GPW \% & Rein & Claim \% & Growth & Excess \% & Combined & InvR & H-Index \\
\hline PT & 1.00 & -0.30 & -0.08 & 0.08 & 0.00 & -0.07 & -0.07 & -0.01 & 0.09 & -0.08 & -0.10 & 0.13 \\
\hline Lev & -0.30 & 1.00 & 0.46 & -0.22 & 0.00 & -0.13 & -0.01 & 0.05 & -0.01 & 0.05 & 0.01 & -0.23 \\
\hline Size & -0.08 & 0.46 & 1.00 & -0.42 & -0.01 & 0.00 & 0.00 & 0.15 & 0.05 & -0.08 & -0.08 & -0.46 \\
\hline CA & 0.08 & -0.22 & -0.42 & 1.00 & 0.05 & -0.16 & 0.01 & 0.01 & 0.03 & -0.03 & 0.16 & 0.18 \\
\hline GPW \% & 0.00 & 0.00 & -0.01 & 0.05 & 1.00 & -0.05 & 0.23 & 0.32 & 0.02 & -0.11 & 0.01 & -0.06 \\
\hline Rein & -0.07 & -0.13 & 0.00 & -0.16 & -0.05 & 1.00 & 0.00 & -0.04 & 0.00 & 0.05 & -0.33 & -0.14 \\
\hline Claim \% & -0.07 & -0.01 & 0.00 & 0.01 & 0.23 & 0.00 & 1.00 & 0.18 & 0.02 & -0.08 & 0.01 & 0.00 \\
\hline Growth & -0.01 & 0.05 & 0.15 & 0.01 & 0.32 & -0.04 & 0.18 & 1.00 & 0.25 & -0.17 & -0.05 & -0.07 \\
\hline Excess \% & 0.09 & -0.01 & 0.05 & 0.03 & 0.02 & 0.00 & 0.02 & 0.25 & 1.00 & -0.04 & 0.00 & 0.00 \\
\hline Combined & -0.08 & 0.05 & -0.08 & -0.03 & -0.11 & 0.05 & -0.08 & -0.17 & -0.04 & 1.00 & -0.04 & 0.11 \\
\hline InvR & -0.10 & 0.01 & -0.08 & 0.16 & 0.01 & -0.33 & 0.01 & -0.05 & 0.00 & -0.04 & 1.00 & -0.06 \\
\hline H-Index & 0.13 & -0.23 & -0.46 & 0.18 & -0.06 & -0.14 & 0.00 & -0.07 & 0.00 & 0.11 & -0.06 & 1.00 \\
\hline
\end{tabular}

Table 3. Correlation matrix of underwriting profit, leverage ratio, firm size, cash ratio, change of gross premium written, reinsurance ratio, change of incurred claims, growth ratio, change of excess capital, combined ratio, investment return and Herfindahl index of the whole industry. 
Table 3 shows the correlation matrix of the 12 firm-specific variables. Underwriting profitability (PT) is negatively correlated to leverage (Lev) and the reinsurance ratio. This suggests that financing activities through debt and reinsurance may reduce profits. Firm size has a positive relationship with leverage (Lev) but a negative one with the cash ratio (CA), which indicates that large firms are relatively more leveraged and hold less cash. Finally, firm size and the Herfindahl index (H-index) are negatively correlated, which suggests that large firms have a relatively concentrated business.

\section{The Model}

Default risk modelling has developed considerably in recent years. Beaver $(1966,1968)$ and Altman (1968) first proposed credit scoring models that calculate the default probability for a firm using accounting-based variables. The structural model, first used by Merton (1974), applies option theory to derive the value of a firm's liabilities in the event of default.

There are several issues arising in the context of such models. Estimating the probability of default on the basis of accounting data amounts to trying to predict a future event using financial statements designed to capture the past performance of a firm; therefore, the obtained estimates might not have strong predictive power about the future status of the firm. Also, Hillegeist et al. (2004) find that, owing to the conservatism principle, fixed assets and intangibles are sometimes undervalued relative to their market prices causing accountingbased leverage measures to be overstated. As for the structural model, the value of a firm's assets is estimated at market prices; however, these may not contain all publicly available default-related information on the firm. Also, the term structure, off-balance and other liabilities are not well specified in structural models when calculating the default threshold of the firm, which may lead to inaccurate estimates of the default probability.

For these reasons, in this paper instead we estimate default probabilities using reduced-form models that have become increasingly popular for individual firms in recent years. Jarrow and Turnbull (1995) first introduced this type of models, which were then extended by Duffie and Singleton (1999). They assume that exogenous Poisson random variables drive the default probability of a firm. A firm will default when the exogenous variables shift from their normal levels. The stochastic process in the model is not directly linked to the firm's assets value. This makes the models more tractable. Duffie et al. (2007) first proposed a doubly stochastic Poisson model with time-varying covariates and then forecast the evolution 
of covariate processes using Gaussian panel vector autoregressions. The model was further developed by Duan et al. (2012), who applied a pseudo-likelihood method to derive the forward intensity rate of the doubly stochastic Poisson processes at different time horizons.

The Poisson process with stochastic intensities has been widely applied to model default events. The specification adopted in this paper assumes that the stochastic intensity has a linear relationship with macroeconomic and firm-specific variables. A doubly-stochastic formulation of the point process for default is proposed by Duffie et al. (2007), with the conditional probability of default within $\tau$ years being given by

$$
q\left(X_{t}, \tau\right)=E\left(\int_{t}^{t+\tau} e^{-\int_{t}^{z}(\lambda(u)+\varphi(u)) d u} \lambda(z) d z \mid X_{t}\right)
$$

where $\mathrm{X}_{\mathrm{t}}$ is the Markov state vector of firm-specific and macroeconomic covariates, and $\lambda_{t}$ (i.e. the conditional mean arrival rate of default measured in events per year) is a firm's default intensity. The firm may exit for other reasons, such as merger and acquisition or transfer of business to other firms, in which case the intensity is defined as $\varphi_{\mathrm{t}}$. Thus the total exit intensity is $\varphi_{\mathrm{t}}+\lambda_{\mathrm{t}}$.

The forward default intensity is given by:

$$
f_{t}(\tau)=\exp \left(\alpha_{0}(\tau)+\alpha_{1}(\tau) X_{t, 1}+\alpha_{2}(\tau) X_{t, 2}+\cdots+\alpha_{k}(\tau) X_{t, k}\right)
$$

and the forward combined exit intensity is defined as:

$$
g_{t}(\tau)=f_{t}(\tau)+\exp \left(\beta_{0}(\tau)+\beta_{1}(\tau) X_{t, 1}+\beta_{2}(\tau) X_{t, 2}+\cdots+\beta_{k}(\tau) X_{t, k}\right)
$$

We use the pseudo-likelihood function derived by Duan (2012) to estimate the forward default intensity. The details of the derivation of its large sample properties can be found Appendix A in Duan's (2012) paper. In short, the pseudo-likelihood function for the prediction time $\tau$ is defined as

$$
\mathcal{L}_{\tau}\left(\alpha, \beta ; \tau_{C}, \tau_{D}, X\right)=\prod_{i=1}^{N} \prod_{t=0}^{T-1} \mathcal{L}_{\tau, i, t}(\alpha, \beta)
$$

Our sample period goes from 0 to $T$ and the frequency is annual. Firm $i$ first appears in the sample at $t_{0 i}$ and $\tau_{D i}$ is the default time while $\tau_{C i}$ is the combined exit time. During the sample period, if firm $i$ exits because of default, then $\tau_{D i}=\tau_{C i}$, otherwise $\tau_{C i}<\tau_{D i}$. As previously explained, $X_{i t}$ are the covariates including common factors and firm-specific 
variables. The prediction horizon $\tau$ is measured in years with $\Delta t=1$, and $\alpha$ and $\beta$ are the model parameters for default and other exit processes respectively.

According to the double stochastic assumption (also known as the conditional independence assumption), firms' default probabilities only depend on common factors and firm-specific variables and are independent from each other, i.e. the default of one firm will not influence other firms’ exit probabilities.

The likelihood function $\mathcal{L}_{\tau, \mathrm{i}, \mathrm{t}}(\alpha, \beta)$ allows for five possible cases for firm $i$ : in the prediction time period it can survive, default, ${ }^{15}$ exit for other reasons (which in our sample means that the insurance firm transferred its business to other firms); it can also exit after or before the prediction time period:

$$
\begin{aligned}
& \mathcal{L}_{\tau, i, t}(\alpha, \beta) \\
& \quad=1_{\left\{t_{0 i} \leq t, \tau_{C i} \geq t+\tau\right\}} P_{t}\left(\tau_{C i}>t+\tau\right)+1_{\left\{t_{0 i} \leq t, \tau_{D i}=\tau_{C i} \leq t+\tau\right\}} P_{t}\left(\tau_{C i} ; \tau_{D i}=\tau_{C i} \leq t+\tau\right)+ \\
& 1_{\left\{t_{0 i} \leq t, \tau_{D i} \neq \tau_{C i}, \tau_{C i} \leq t+\tau\right\}} P_{t}\left(\tau_{C i} ; \tau_{D i} \neq \tau_{C i}, \& \tau_{C i} \leq t+\tau\right)+1_{\left\{t_{0 i}>t\right\}}+1_{\left\{t_{C i}<t\right\}}
\end{aligned}
$$

where

$P_{t}\left(\tau_{C i}>t+\tau\right)=\exp \left[-\sum_{s=0}^{\tau-1} g_{i t}(s) \Delta t\right]$

$P_{t}\left(\tau_{C i} ; \tau_{D i}=\tau_{C i} \leq t+\tau\right)$

$=\left\{\begin{array}{c}1-\exp \left[-f_{i t}(0) \Delta t\right], \text { when } \tau_{C i}=t+1 \\ \exp \left[-\sum_{s=0}^{\tau_{C i}-t-2} g_{i t}(s) \Delta t\right] *\left\{\exp \left[-f_{i t}\left(C_{i t}-t-1\right) \Delta t\right]-\exp \left[-g_{i t}\left(\tau_{C i}-t-1\right) \Delta t\right]\right\}, \\ \text { when } t+1<\tau_{C i} \leq t+\tau\end{array}\right\}$

$P_{t}\left(\tau_{C i} ; \tau_{D i} \neq \tau_{C i}, \& \tau_{C i} \leq t+\tau\right)$

$=\left\{\begin{array}{c}\exp \left[-\sum_{s=0}^{\tau_{C i}-t-2} \exp \left[-f_{i t}(0) \Delta t\right]-\exp \left[-g_{i t}(0) \Delta t\right], \text { when } \tau_{C i}=t+1\right. \\ \left.g_{i t}(s) \Delta t\right] *\left\{\exp \left[-f_{i t}\left(\tau_{C i}-t-1\right) \Delta t\right]-\exp \left[-g_{i t}\left(\tau_{C i}-t-1\right) \Delta t\right]\right\}, \\ \text { when } t+1<\tau_{C i} \leq t+\tau\end{array}\right\}$

\footnotetext{
${ }^{15}$ Default events are collected from SynThesys Non-Life and include insolvent, in liquidation, placed in administration and dissolved.
} 
The pseudo-likelihood function $\mathcal{L}_{\tau, i, t}(\alpha, \beta)$ can be maximized numerically to obtain the estimated parameters $\hat{\alpha}$ and $\widehat{\beta}$. Owing to the overlapping nature of this function, the inference is not immediately clear. For example, at time $t_{5}$ and the prediction horizon $\tau=2$, firm $A$ 's default over the 2-year period starting 1 year ahead ( $t_{4}$ to $\left.t_{6}\right)$ will be correlated with firm's B default in the next time period ( $t_{6}$ in this case).

In addition, the pseudo-likelihood function can be decomposed into two processes $\alpha$ and $\beta$, and each process can be further decomposed into different prediction horizon $\tau$. As a result, estimates of $\hat{\alpha}$ and $\widehat{\beta}$ can be obtained at the same time.

$$
\begin{aligned}
& \mathcal{L}_{\tau}(\alpha(s))=\prod_{i=1}^{N} \prod_{t=0}^{T-s-1} \mathcal{L}_{i, t}(\alpha(s)), s=0,1, \ldots, \tau-1 \\
& \mathcal{L}_{\tau}(\beta(s))=\prod_{i=1}^{N} \prod_{t=0}^{T-s-1} \mathcal{L}_{i, t}(\beta(s)), s=0,1, \ldots, \tau-1 .
\end{aligned}
$$

In order to test the robustness of the model, we split the sample by using data up to 2010, 2011, 2012, 2013 and 2014, and then we calibrate the model by using the four different samples.

\section{Empirical Results}

\subsection{Estimations Results}

In our model, the logarithm of forward default intensity has a linear relationship with the covariates:

$$
\lambda_{t}(\tau)=\alpha_{0}(\tau)+\alpha_{1}(\tau) X_{t, 1}+\alpha_{2}(\tau) X_{t, 2}+\cdots+\alpha_{k}(\tau) X_{t, k}
$$

$X_{t, k}$ includes the following factors: GDP growth, real interest rate, real exchange rate, FDI, wholesale price change, underwriting profit, leverage, firm's size, cash ratio, gross premium written change, reinsurance, incurred claimed change, firm's growth, excess capital change, investment return, combined ratio, Herfindahl index, derivative dummy and organizational form.

Table 4 shows the main estimation results based on four different samples. Other exit (i.e. transferring business to others) outputs can be found in Appendix B 


\section{Table 4}

\section{Estimations Results}

\begin{tabular}{|c|c|c|c|c|c|}
\hline & 2010 & 2011 & 2012 & 2013 & 2014 \\
\hline \multicolumn{6}{|l|}{ Parameters } \\
\hline \multirow[t]{2}{*}{$\mathrm{C}$} & $-19.364 * * *$ & $-25.172 * * *$ & $-24.116^{* * *}$ & $-25.313 * * *$ & $-26.959 * * *$ \\
\hline & $(-6.143)$ & $(-7.441)$ & $(-7.798)$ & $(-8.054)$ & $(-8.411)$ \\
\hline \multirow[t]{2}{*}{ GDP_growth } & -0.092 & -0.019 & -0.028 & -0.010 & -0.013 \\
\hline & $(-0.062)$ & $(-0.083)$ & $(-0.087)$ & $(-0.090)$ & $(-0.098)$ \\
\hline \multirow[t]{2}{*}{ Real_IR } & 0.009 & 0.034 & $0.085 * *$ & $0.098 * *$ & $0.109 * *$ \\
\hline & $(-0.055)$ & $(-0.045)$ & $(-0.042)$ & $(-0.043)$ & $(-0.043)$ \\
\hline \multirow[t]{2}{*}{ Real_EXrate } & -0.003 & 0.006 & 0.006 & 0.007 & 0.007 \\
\hline & $(-0.009)$ & $(-0.011)$ & $(-0.012)$ & $(-0.012)$ & $(-0.013)$ \\
\hline \multirow[t]{2}{*}{ FDI \% } & -0.027 & 0.008 & -0.052 & -0.109 & -0.073 \\
\hline & $(-0.086)$ & $(-0.089)$ & $(-0.067)$ & $(-0.075)$ & $(-0.072)$ \\
\hline \multirow[t]{2}{*}{$\begin{array}{l}\text { Wholesale } \\
\text { Price \% }\end{array}$} & $17.830 * * *$ & $23.977 * * *$ & $21.153^{* * *}$ & $21.988 * * *$ & $22.777 * * *$ \\
\hline & $(-5.355)$ & $(-6.754)$ & $(-6.691)$ & $(-6.998)$ & $(-7.452)$ \\
\hline \multirow[t]{2}{*}{$\begin{array}{l}\text { Credit by } \\
\text { Financial \% }\end{array}$} & $-5.103^{* *}$ & $-6.674 * * *$ & $-5.011 * * *$ & $-4.824 * * *$ & $-4.323 * * *$ \\
\hline & $(-2.001)$ & $(-2.244)$ & $(-1.650)$ & $(-1.669)$ & $(-1.586)$ \\
\hline \multirow[t]{2}{*}{ PT } & $-4.112 * * *$ & $-4.409 * * *$ & $-4.815^{* * *}$ & $-4.867 * * *$ & $-4.895 * * *$ \\
\hline & $(-1.328)$ & $(-1.143)$ & $(-1.204)$ & $(-1.224)$ & $(-1.284)$ \\
\hline \multirow[t]{2}{*}{ Lev } & $1.863 * * *$ & $1.840 * * *$ & $1.966^{* * *}$ & $1.973 * * *$ & $1.972 * * *$ \\
\hline & $(-0.311)$ & $(-0.296)$ & $(-0.311)$ & $(-0.313)$ & $(-0.323)$ \\
\hline \multirow[t]{2}{*}{ Size } & 0.030 & 0.028 & 0.016 & 0.018 & 0.022 \\
\hline & $(-0.061)$ & $(-0.059)$ & $(-0.061)$ & $(-0.061)$ & $(-0.062)$ \\
\hline \multirow[t]{2}{*}{ CA } & -0.182 & -0.160 & -0.228 & -0.224 & -0.210 \\
\hline & $(-0.574)$ & $(-0.549)$ & $(-0.560)$ & $(-0.561)$ & $(-0.562)$ \\
\hline \multirow[t]{2}{*}{ GPW\% } & -0.180 & $-0.435 * * *$ & $-0.416 * * *$ & $-0.413 * * *$ & $-0.414 * * *$ \\
\hline & $(-0.175)$ & $(-0.109)$ & $(-0.108)$ & $(-0.109)$ & $(-0.111)$ \\
\hline Rein & $1.109 * * *$ & $1.003 * * *$ & $1.091^{* * *}$ & $1.108 * * *$ & $1.123 * * *$ \\
\hline
\end{tabular}




\begin{tabular}{lrrrrr} 
& $(-0.275)$ & $(-0.259)$ & $(-0.270)$ & $(-0.279)$ & $(-0.304)$ \\
Claim\% & $0.041^{* * *}$ & $0.040^{* * *}$ & $0.055^{* * *}$ & $0.053^{* * *}$ & $0.052^{* * *}$ \\
& $(-0.015)$ & $(-0.015)$ & $(-0.015)$ & $(-0.015)$ & $(-0.015)$ \\
Growth & 0.014 & -0.010 & 0.055 & 0.060 & 0.059 \\
& $(-0.120)$ & $(-0.105)$ & $(-0.115)$ & $(-0.116)$ & $(-0.118)$ \\
Eecess\% & $-0.287 * *$ & $-0.281 * *$ & $-0.230 *$ & $-0.231 *$ & $-0.229 *$ \\
& $(-0.122)$ & $(-0.113)$ & $(-0.122)$ & $(-0.123)$ & $(-0.123)$ \\
InvR & $-25.362 * * *$ & $-25.449 * * *$ & $-25.184 * * *$ & $-24.899 * * *$ & $-24.849 * * *$ \\
& $(-5.517)$ & $(-4.585)$ & $(-5.832)$ & $(-6.190)$ & $(-7.364)$ \\
Combined Ratio & $0.024 * * *$ & $0.023 * *$ & $0.025 * *$ & $0.025 * *$ & $0.026 * * *$ \\
& $(-0.009)$ & $(-0.010)$ & $(-0.010)$ & $(-0.010)$ & $(-0.010)$ \\
Herfindahl index & 0.606 & 0.508 & 0.439 & 0.435 & 0.429 \\
& $(-0.380)$ & $(-0.367)$ & $(-0.373)$ & $(-0.374)$ & $(-0.377)$ \\
Derivative & $0.607 * *$ & $0.641 * *$ & $0.655^{* *}$ & $0.653 * *$ & $0.654 * *$ \\
Dummy & $(-0.278)$ & $(-0.281)$ & $(-0.276)$ & $(-0.275)$ & $(-0.275)$ \\
Organizational & 0.509 & $0.528 *$ & $0.553^{*}$ & $0.559 *$ & $0.642 * *$ \\
\hline & $(-0.321)$ & $(-0.316)$ & $(-0.308)$ & $(-0.310)$ & $(-0.303)$ \\
\hline
\end{tabular}

* Significant at $10 \%$

** Significant at 5\%

*** Significant at $1 \%$

Table 4. Coefficients of constant, GDP growth, real interest rate, real exchange rate, foreign direct investment \%, whole sale price \%, credit provided by financial institutions \%, underwriting profit, leverage, size, cash ratio, gross premium written \%, reinsurance, incurred claims \%, growth, excess capital, combined ratio, investment return, Herfindahl index, derivative dummy and organizational form based on five different samples using data from 1985 to 2010, 2011, 2012, 2013 and 2014 respectively. Results of multi-periods (5 years' horizon) estimation which based on full sample (1985-2014) can be found in Appendix B and Appendix C. 
Table 4 shows the results for the sample periods 1985 to 2010, 2011, 2012, 2013 and 2014 respectively. Overall, most our results are in line with those of Adam et al., (2003). Leverage, profit, reinsurance and organizational form ${ }^{16}$ are significant factors both for assessing the credit risk of insurance firms and determining the quality of credit rating. On the other hand, firm size and growth are not significant. ${ }^{17}$ Further, we find that macroeconomic and firmspecific factors (the change of credit provided by financial institutions, whole sale price change, investment profitability, combined ratio, and the usage of financial derivatives) are also important, and therefore should not be neglected. As far as we are aware ours is the first study documenting their key role in determining the credit risk of insurance firms.

In general, GDP growth, the real interest rate and the change in wholesale prices have a positive effect on default intensity that could lead to a higher default probability (PD). Writing Profitability and investment profitability are negatively correlated with the default intensity. This suggests that high profitable firms are less likely to become insolvent. Our results are consistent with those of Titman and Wessels (1988) and Frank and Goyal (2009), and also with the findings of Carson and Scott (1997) and Bouzouita and Young (1998), who show that higher liquidity is associated with a higher credit rating. Therefore, firms holding more capital tend to have higher liquidity and a lower default probability. In general, large firms typically have a good reputation and therefore it is easier for them to obtain credit in the market.

Bouzouita and Young (1998) find that large insurers are less likely to default. Our results suggest that firm size is not a significant determinant of the solvency of insurance firms. Firms with larger gross premium written will not only have cash inflows in the short term but also potential claims in the long term. The one-year PD shows that writing more premiums will lower an insurer's default probability.

Highly leveraged firms are less likely to survive during recessions and therefore normally have a higher PD. Ad hoc structured reinsurance may reduce the credit risk exposure - for example, Adams (1996) shows that reinsurance improves the ability of the primary insurer to survive an external economic shock. However, we find a positive relationship between reinsurance and PD, which suggests that heavily reinsured firms are more likely to default.

\footnotetext{
16 'Business Activitiy' in Adam et al., (2003)

${ }^{17}$ This could be due to the different datasets used. Ours covers 363 general insurance firms and data from 1985 to 2014. Adam et al. (2003) instead only consider 40 firms rated by A.M. Best plus 25 firms rated by S\&P and include both general insurance and life insurance firms into the model.
} 
Insurers transfer part or all of their risk to other insurers through reinsurance and release capital reserves; in this way they have resources to write new business. Our results show that the effect of negative perspective of reinsurers cannot be ignored. That is, insurers are exposed to the counterparty risk of reinsures (e.g. when reinsurers are insolvent or run-off, insurers will have to pay the claims to the policy-holders) and their fast-growing business may lead to higher potential losses in the future. One important question is whether using derivatives increases the counterparty risk or is only useful for hedging. For example, derivatives could be used for hedging risk, but Shiu (2011) shows that this could also increase the exposure to counterparty risk. Our findings indicate that the use of derivatives may increase the probability of a firm becoming insolvent. This has important implications for assessing risk in this industry.

\subsection{Overall Probability of Default for the General Insurance Industry}

In this section we estimate the default probabilities for all active firms as well as the survival firms. This is in fact the first study using historical default risk for all active firms based on their individual PD. We also consider the performance of insurance firms during natural disasters and financial distress times (that is, at times when insurers are vulnerable and more likely to default). Figure 1 below shows the probability of default for the General Insurance industry from 1986 to 2014. The PDs are calculated using the full-sample parameter estimates.

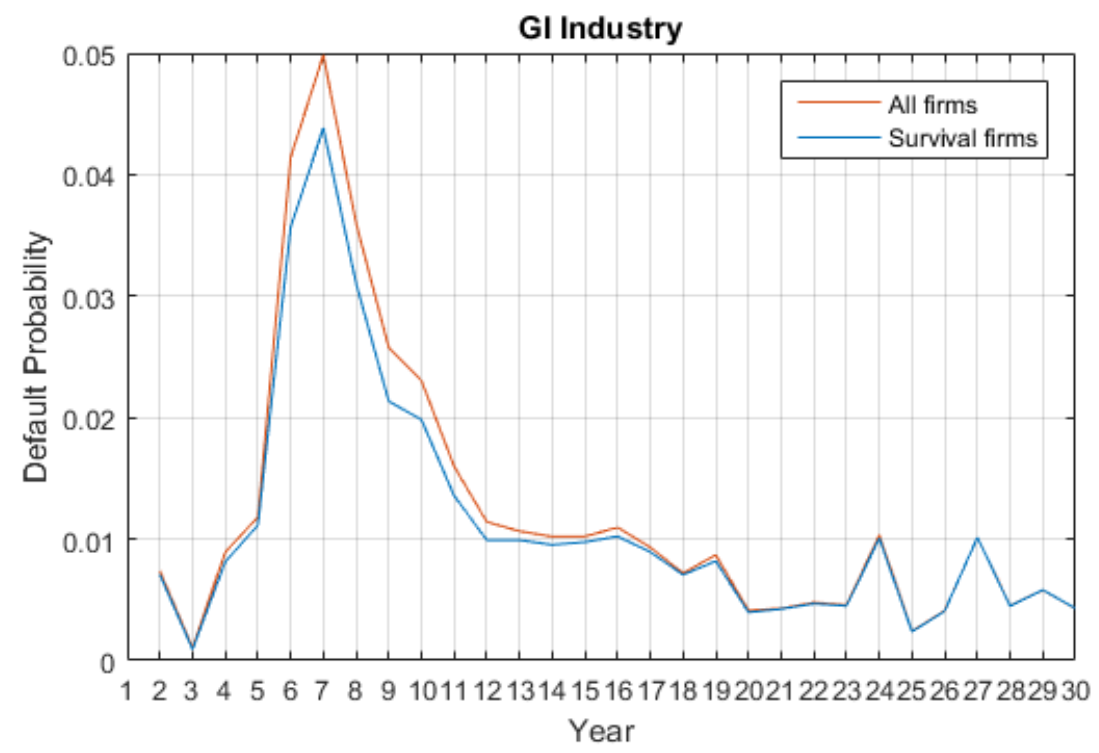

Figure 1. PD of all firms. One-year default probability of GI firms from 1986 to 2014. 


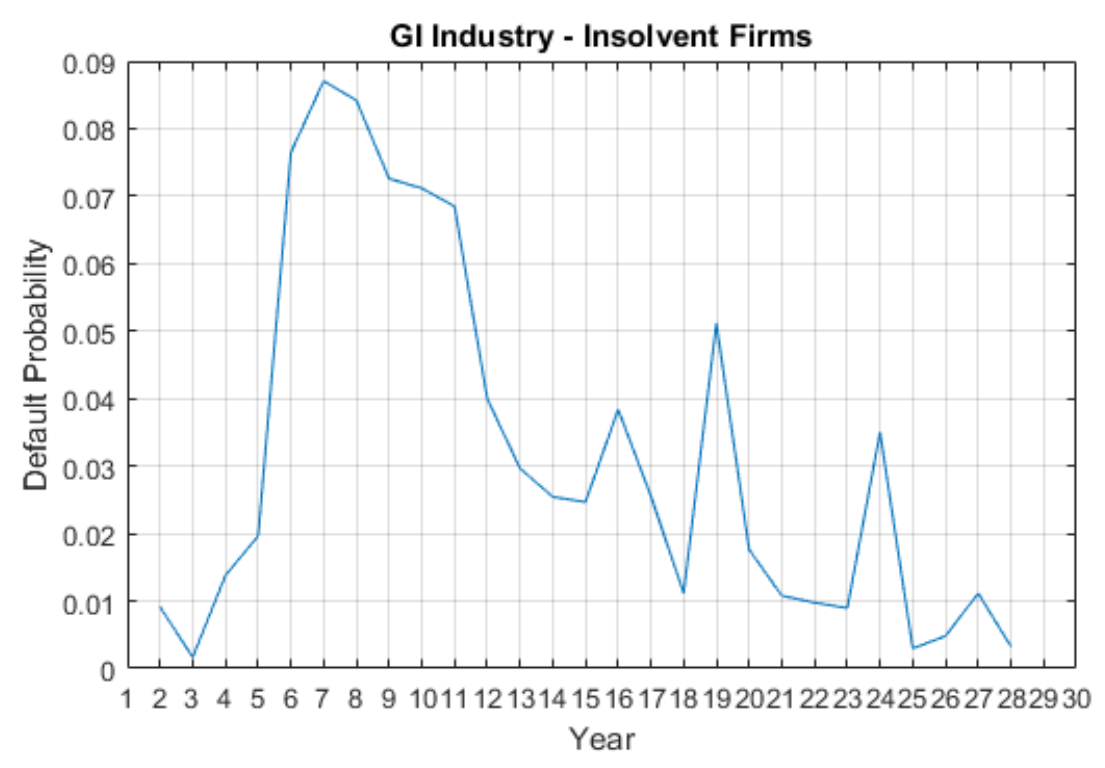

Figure 2. PD of insolvent firms. One-year default probability of GI insolvent firms from 1986 to 2013.

Figure 1 and Figure 2 shows that the PD of insolvent firms is much higher and fluctuates more compared to the whole GI industry (despite the different sample size of solvent and insolvent firms, the median PD reported in Appendix C shows the same trend as in Figure 1 and Figure 2). The highest PD of insolvent firms is about 0.09, which is almost double that of the whole industry. For the GI industry, the PD peaks around the early 90s and then decreases until 2000. The PD is relatively low but increased sharply in 2008, at the time of the global financial crisis. The PD of insolvent firms peaks around 1990 and then decreases until 1998. There are two spikes in 2000 and 2003, before the 2008 global financial crisis. The average PD for default firms is 317 bps and 124 bps for the whole industry (112 bps for survival firms). The standard deviation for default firms is 0.0276 , which is much higher than for the whole industry (0.0119) and survival firms (0.0101). In general, default firms are more risky compared to the whole GI industry. 


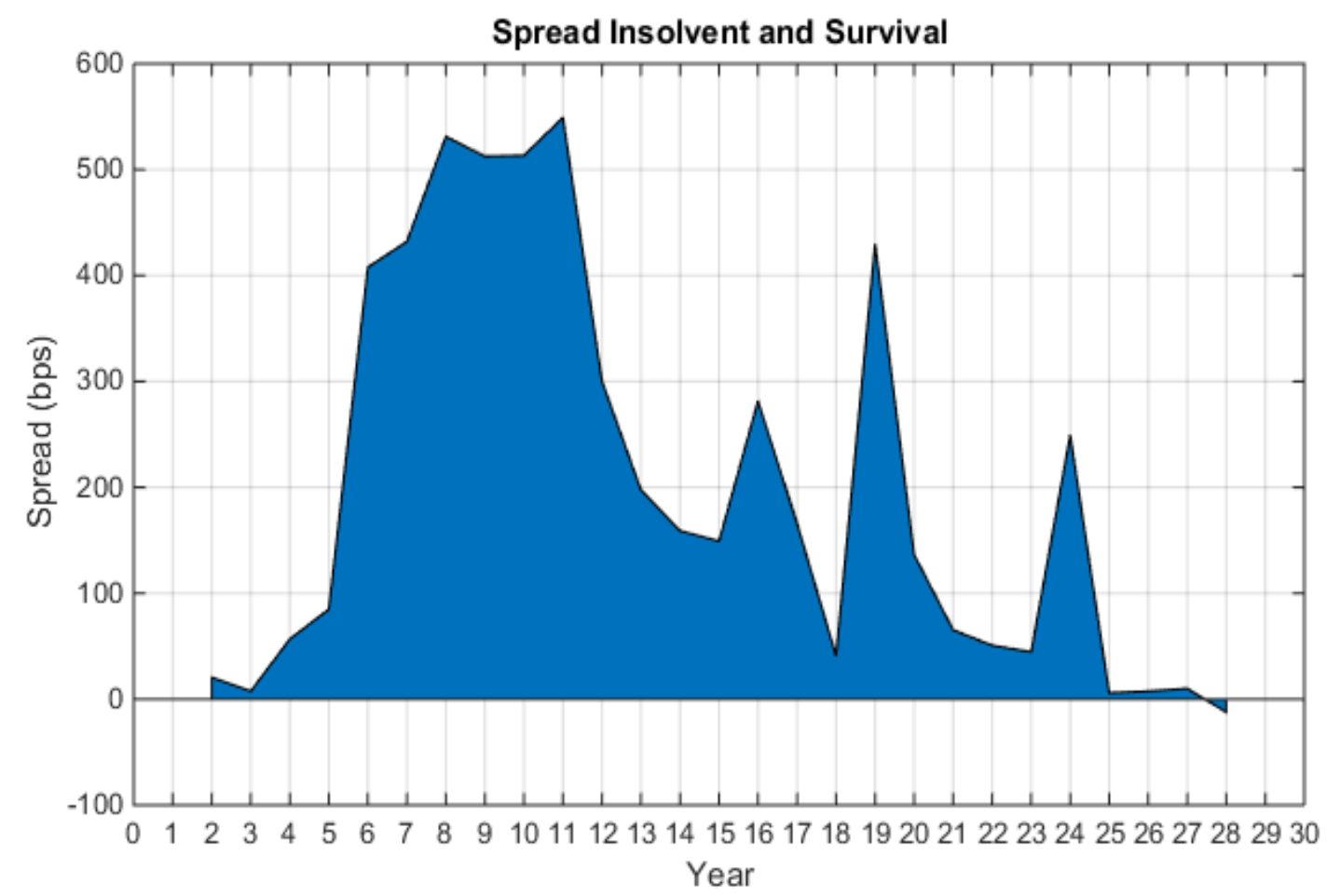

Figure 3. PD of Survival firms and spread between default and survival firms. One-year default probability of survival firms and the spread between survival and default firms from 1986 to 2013.

Figure 3 shows a large PD spread between insolvent firms and the whole GI industry during the early 90s and a sharp rise in 2000 and 2003. It is generally positive before 2009, and it increases rapidly during the financial crisis, which indicates that all insolvent firms faced a worse financial situation and are more vulnerable than the whole GI industry. After 2008 it is much smaller or even negative.

To sum up, the default probability of the General Insurance industry varies over time and the PD of insolvent firms is more volatile than that of the survival firms. High PDs are usually found when there are disasters such as floods; this indicates that, unlike other financial institutions, insurance firms are relatively stable but very sensitive to natural disasters. The high PDs around the time of the 2008 financial crisis suggest that the insurance and banking industries may be closely correlated (further research is needed on this issue, which is beyond the scope of the present paper). Regulators should consider these interactions and be aware of the contagion effect in distress times. 


\subsection{Probability of Default for Different Business Lines}

In general, insurance firms have business in different sectors and firms may change their main business line over time. In addition to business concentration, the change in the credit risk in different sectors has also important implication for the regulators' supervision and policy-making decisions. This crucial issue has been completely overlooked in the literature. Here we extend the credit risk analysis to the insurance firms’ business line.

On the basis of the gross premium written by each firm for different business lines, we classify insurance firms into 7 groups: 1 . Accident \& Health; 2. Motor; 3. Marine, Aviation \& Goods in Transit; 4. Third-party Liability; 5. Financial Loss; 6. Household\& Domestic All risks and Property; 7. Miscellaneous.

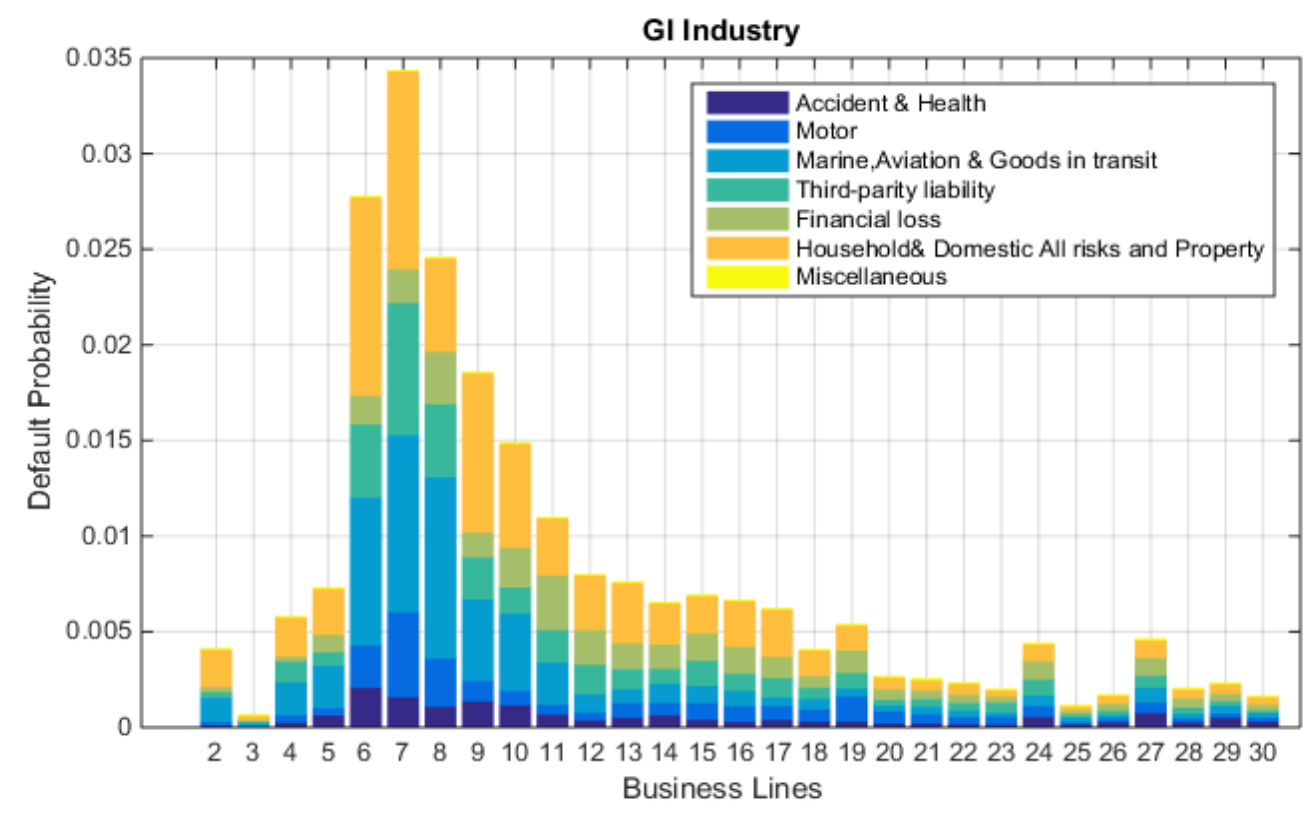

Figure 4. PD of 7 Groups. One-year default probability which is decomposed to 7 groups' PD from 1986 to 2014. 


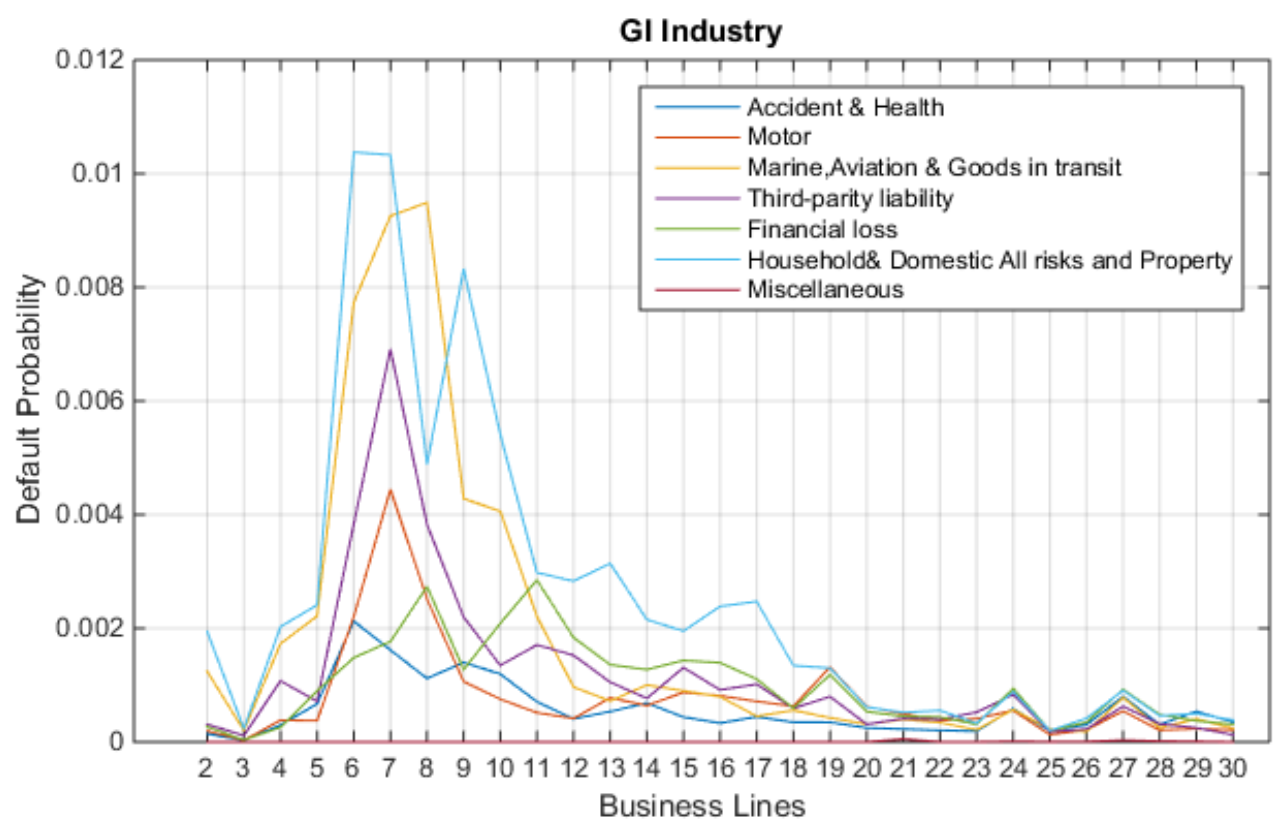

Figure 5. PD of 7 Groups. One-year default probability 7 groups which contain PD from 1986 to 2014.

Before 1995, Household \& Domestic All Risk and Property (group 6) has the highest default probability, with Marine, Aviation \& Goods in Transit (group 3) having the second highest. Third-party Liability (group5) has the third highest, and Accident \& Health (group 1) the lowest. After 1995, the PDs of group 6 and group 3 are decreasing, while those of group 5 and group 1 are fluctuating around their average. The PDs of most groups exhibit an upward trend during the 2008 financial crisis, the exceptions being Marine, Aviation \& Goods in Transit as well as Miscellaneous, which are relatively flat. After the financial crisis, Financial Loss and Household \& Domestic All Risk \& property become the riskiest groups.

Insurance firms are generally very vulnerable when natural disasters happen. Decomposing the PD of the insurance industry into different business lines reveals clear differences around the early 90s. Household, Property, Motor, Transportation and Third-party Liability are the riskiest businesses because they are more likely to be exposed to catastrophes such as floods, earthquakes etc. However, the PDs of all business lines have the same upward trend in distress times. These findings suggest that regulators might want to consider the varying composition of the premium written by insurance firms when setting capital requirements.

\subsection{Default Clustering and Systemic Risk}

Since most insurance firms are non-public firms with a short history, very few of them are rated by credit rating agencies (e.g. Moody’s, S\&P, Fitch and A\&M Best). Adam et al. 
(2003) analyse 65 non-life and life firms rated by A.M. Best and S\&P, while our sample includes more than 300 GI firms. Using the estimation results from our model (see Table 4), we calculate PD for all available firms (see equation 2). We then extend the analysis to investigate the joint default risk. We compute pair correlations of firms for different quantiles, and use the average value to obtain the default correlation. Previous studies such as Das et al. (2007) find strong default correlations among corporate obligors. It is interesting to establish whether insurance firms are likely to default jointly when their individual PDs are high. Also, high PD correlations may suggest that insurers are affected by common factors besides firm-specific factors.

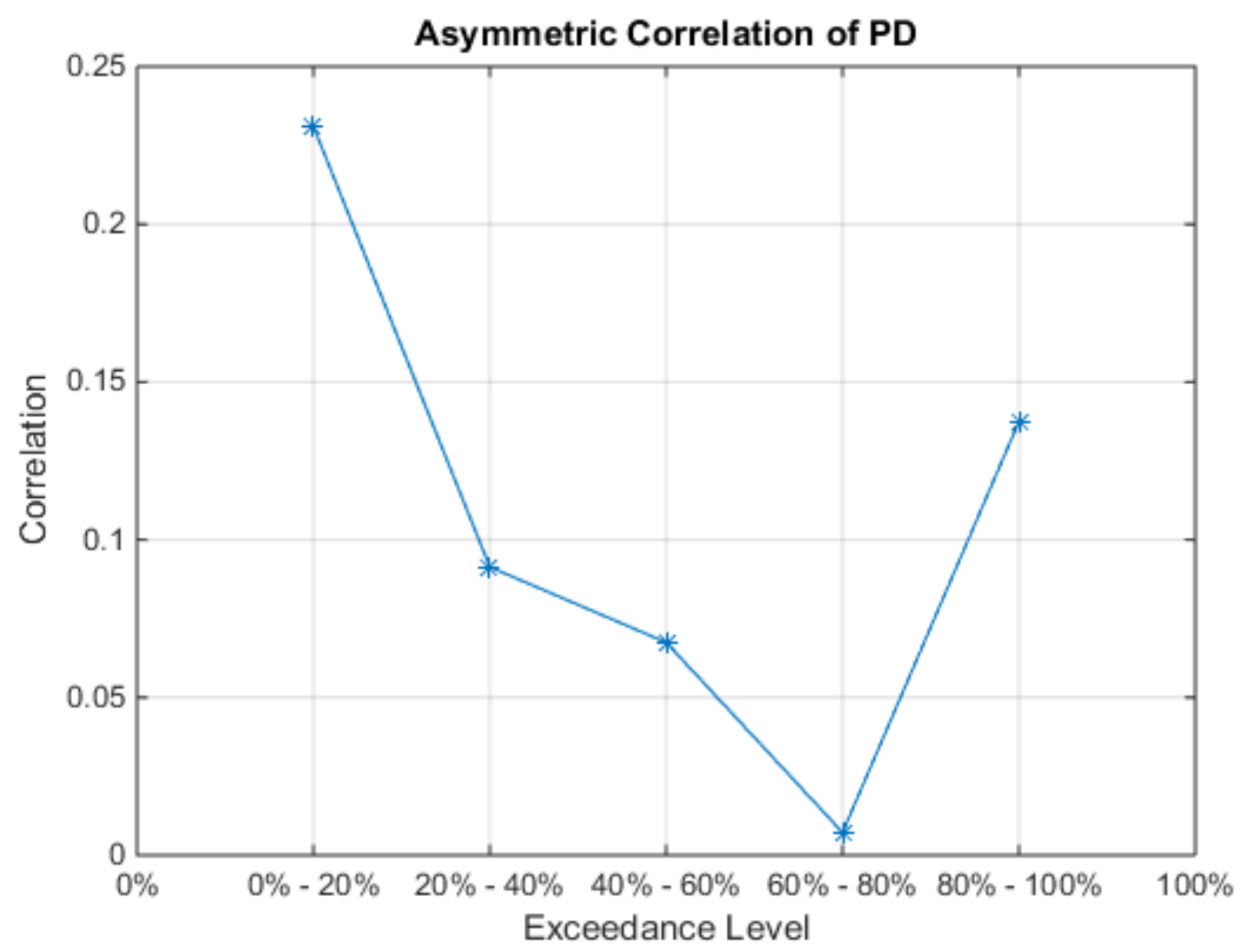

Figure 6. Asymmetric Correlation of PDs. Correlation of PDs for the different PD quantiles in our study. First rank the PD of the whole GI industry (average PD of all firms at the year) from the lowest to highest. Then we find exceedance levels according the GI industry PD. The lowest quantile $0 \%-20 \%$ indicates the least risky years and the highest $80 \%-100 \%$ quantile mean the most risky years of GI industry. And then we calculate average correlations of each pairs in the same group. 
Figure 6 shows the average pair PD correlations of all firms within different groups (from low risky $0 \%-20 \%$ to high risky $80 \%-100 \%$ ) based on data for the period 1985-2014. The highest PD correlations are found at the $0 \%-20 \%$ quantile, and the second highest in the riskiest group $80 \%-100 \%$. The fact that the highest correlation is that between insurers with the lowest PD suggests that when insurance firms are less exposed to risk there is a more important role for common factors, in our case macroeconomic factors such as the credit supply and wholesale price changes. Insurers within the highest $80 \%-100 \%$ quantile have the second highest PD correlation, which indicates that their credit risk is affected by both common and firm-specific factors. The observed pattern for PD correlations for different quantiles supports our choice of considering macroeconomic factors as well as firm-specific factors. Overall, our empirical results are in line with those of Bell and Keller (2009), who show that insurers are less interconnected than banks and there is a lower contagion effect among them. The average PD correlation across firms is 0.1069 . The PDs for the $20 \%$ quantile has the highest correlation (0.2311). The lowest correlation is 0.0072 , while the PD correlation for the group ' $40 \%$ - 60\%' is much higher (0.0675), and the PD correlation for the group ' $20 \%$ - 40\%' is slightly higher (0.0914). The ' $80 \%-100 \%$ ' group has the second largest PD correlation (0.1375); this is not very different from the industry average, and points to some default clustering. The highest PD correlation is found for the group ' $0 \%-20 \%$ ', which suggests that in safe times most insurance firms are in a good financial situation. 


\subsection{Reinsurance and Default Risk}
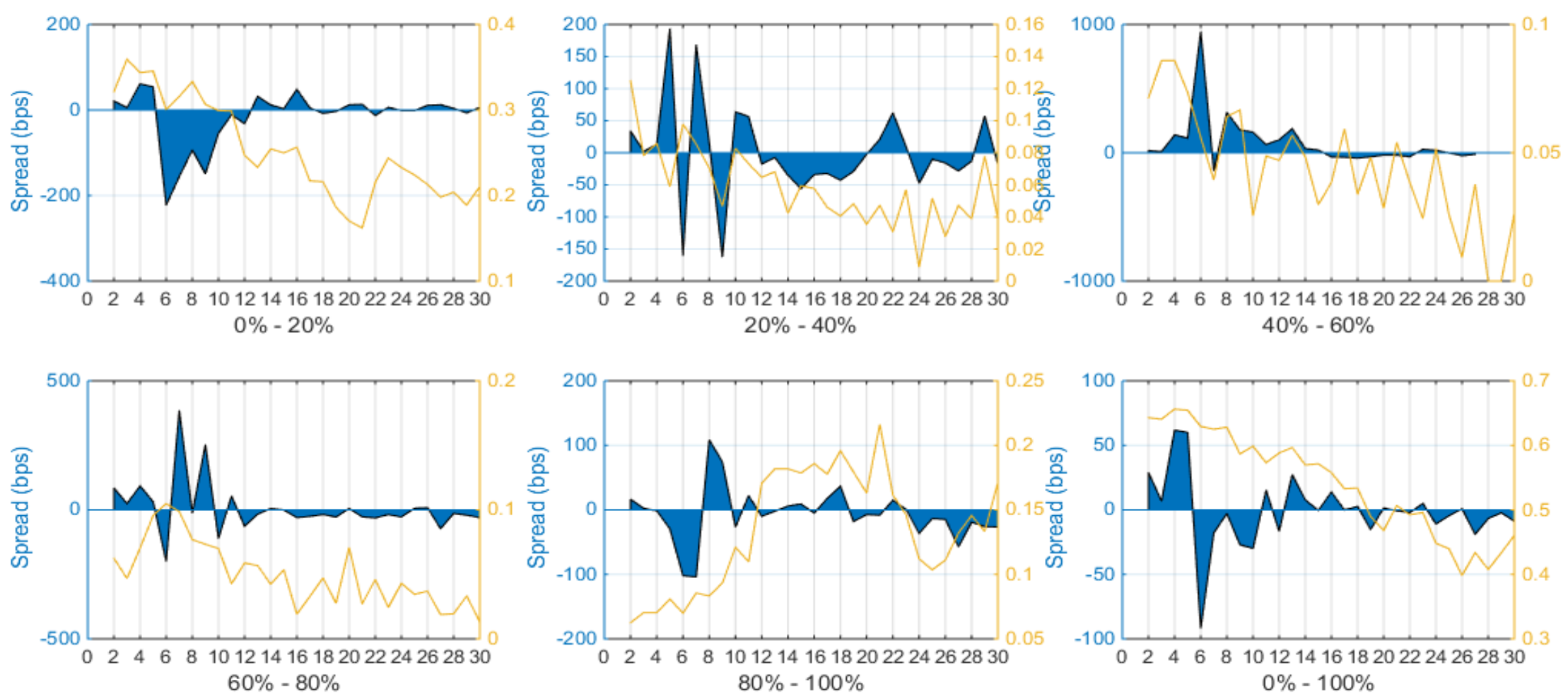

Figure 7. Credit spread when taking Reinsurance. Credit spread between firms accepting reinsurance and firms not accepting reinsurance at different levels (full sample calibration). Orange line: percentage of firms with reinsurance accepted at certain level; blue line: credit spread. 
Previous papers show that corporate hedging decisions such as reinsurance affect the strategic performance of firms (Harris and Raviv, 1991; Adam et al., 2007). Reinsurance is a pure hedging contract that enables primary insurers to transfer risks to third parties. Harrington and Niehaus (2003) argue that it is important because solvency risk matters to both policy holders and regulators.

Since the counter-party risk of reinsurance cannot be ignored, the technical provision of reinsurance has been incorporated into Solvency II. Next, we investigate the performance of firms when they use the reinsurance market. We first classify them into different groups based on the percentage of reinsurance they accept relative to their total written gross premium, and then we analyse the credit spread of firms who accepted reinsurance across the different groups. Aunon-Nerin and Ehling (2008) show that indemnity contracts such as reinsurance contracts are pure hedging instruments. Adam and Upreti (2015) find that reinsurance enables primary insurers to have sufficient risk capacity for planning and pricing new business lines. Therefore, insurers can be exposed to new risks through risk financing, and reinsurers (i.e. firms accepting reinsurance) to claims volatility and potential loss events, but the latter receive a share of annual premiums written.

The maximum spreads for each group are 61 bps, 194 bps, 945 bps, 386 bps, 109 bps, and 62 bps respectively, and their standard deviations 0.0064, 0.0073, 0.0198, 0.0104, 0.0042 and 0.0027. For each group, we calculate the credit spread between firms accepting reinsurance and firms not accepting it.

Figure 7 shows that the lowest 20\% firms have a negative spread, especially during the early 90s, vis-à-vis the firms that do not use the reinsurance market. This may indicate that firms that are less involved with the reinsurance market often have good creditworthiness and take reinsurance as part of their business plan. ${ }^{18}$ By contrast, firms accepting $20 \%$ to $40 \%$ reinsurance can have either positive or negative spreads at different points in time in the sample period. During the financial crisis, their spread vis-à-vis firms not accepting reinsurance is negative. This may reflect their risk management strategy aimed at reducing potential losses during distress times. For the group of firms accepting between $40 \%$ to $60 \%$

\footnotetext{
${ }^{18}$ Through reinsurance, firms will have less liability, fewer reserves requirement, but release more capital to write new business or investment in other products.
} 
and $60 \%$ to $80 \%$ reinsurance, the spread is negative most of the time, except during the $90 \mathrm{~s}^{19}$ Finally, for the group accepting more than $80 \%$ reinsurance the spread peaked during the early 90s (at the time of the Burns' Day Storm), and during the financial crisis becomes relatively small and sometimes negative.

Concerning firm size, the percentage of firms in each group changes over time. The total percentage of firms accepting reinsurance peaked in 1988 and decreases afterwards. Most firms accept less than 20\% reinsurance, and this percentage has been is decreasing since 1987. Less than $50 \%$ of firms have accepted $20 \%$ to $80 \%$ reinsurance, most of the time, in the last 30 years. There are more than 15\% of firms in the upper 20\% group between 1996 and 2005, when this percentage peaked.

The average spread between firms accepting reinsurance and those not accepting it is only -1 bps, which indicates only a slightly smaller credit risk for the former. In our sample period there are 12 years with a positive spread, and 17 years with a negative one. The results imply that firms accepting reinsurance have a lower default probability, especially during bad times (i.e. the Burns' Day Storm in the early 90s and 2008 financial crisis). This is a new and important result. Firms taking reinsurance may choose a more determined risk management strategy and therefore buy good-quality reinsurance to help reduce risk in distress times. Doherty and Tinic (1981) find that reinsurance contracts make primary insurers manage cash flow volatility more effectively, and result in better future underwriting capacity, and lower insolvency probability. Our results show that, on the other hand, reinsurers also benefit from indemnity contracts resulting in lower default probabilities.

\section{Conclusions}

This paper analyses the credit risk of general insurance (GI) firms in the UK using a unique dataset. We estimate a reduced-form model to assess the credit risk of GI firms by considering both insolvency and other types of exit such as transferring business. Our results show that most classic risk factors (for example, profitability, leverage and reinsurance etc.) are significant determinants of the credit risk of insurers. However, in contrast to other studies, we show that macroeconomic factors (GDP growth, interest rate, whole sale price and credit provided by financial institutions) and firm-specific factors (underwriting profit,

\footnotetext{
${ }^{19}$ The Burns' Day Storm occurred on 25-26 January 1990 over north-western Europe and is one of the strongest European windstorms on record. Winds of up to $100 \mathrm{mph}$ killed 97 people and caused $£ 3.37$ billion worth of damage, the most costly weather event for insurers in British history.
} 
leverage, growth premium written, reinsurance, incurred claims, excess capital, combined ratio, investment profit, usage of derivatives and organizational form) are also crucial for assessing the credit risk of General Insurance firms. This represents new and interesting evidence.

Further, we investigate the credit risk of firms with different business lines. We show that in the early 90s, owing to natural disasters, the group Household \& Domestic All Risk had the highest credit risk, while after the financial crisis Third-party Liability became the riskiest sector. Our time-varying estimates of PD could be used as an early warning for risky sectors to which regulators might want to apply more stringent minimum capital requirements. We also show that the joint default correlation for different insurance firms is low, but there is a default clustering.

Finally, our findings indicate that different reinsurance levels affect the credit risk of insurance firms. Reinsurers can benefit from reinsurance contracts that have a lower default probability. This has implications for regulators of GI firms under the coming Solvency II that incorporates reinsurance into the technical provision calculations. 


\section{References}

Acharya, Viral V., J. Biggs, M. Richardson, S. Ryan, 2009. On the Financial Regulation of Insurance Companies, Working Paper, New York University.

Adams, M.B., 1996. The reinsurance decision in life insurance firms: An empirical test of the risk-bearing hypothesis. Accounting and Finance 36, 15-30.

Adams M.B., Burton B., \& Hardwick P., 2003. The determinants of credit ratings in the United Kingdom insurance industry. Journal of Business Finance and Accounting. 30 (3-4): 539-572. DOI: 10.1111/1468-5957.00007.

Adams, M.B and Upreti Vineet, 2015. The strategic role of reinsurance in the United Kingdom's (UK) non-life insurance market. Journal of Banking \& Finance 61 (2015) 206219.

Adam, T., Dasgupta, S., Titman, S., 2007. Financial constraints, competition, and hedging in industry equilibrium. Journal of Finance 62, 2445-2473.

Altman E. I., 1968. Financial Ratios, Discriminant Analysis, and the Prediction of Corporate Bankruptcy. Journal of Finance 23:589-609.

Aunon-Nerin, D., Ehling, P., 2008. Why firms purchase property insurance. Journal of Financial Economics 90, 298-312.

Barell, R., Davis, E.P., Karim, D., Liadze, I., 2010.Bank regulation, property prices and early warning systems for banking crises in OECD countries. Journal of Banking and Finance. 34, 2255-2264.

Beaver W., 1966. Financial Ratios as Predictors of Failure. Journal of Accounting Research 5: 71- 111.

Beaver W., 1968. Market Prices, Financial Ratios and Prediction of Failure. Journal of Accounting Research 6 (2), 179-192.

Bell and Keller, 2009. Insurance and Stability: The Reform of Insurance Regulation, Zurich Financial Services Group Working Paper.

Berger, L.A., Cummins, J.D., Tennyson, S., 1992. Reinsurance and the liability insurance crisis. Journal of Risk and Uncertainty 5, 253-272.

Borio, C., Drehmann, M., 2009.Assessing the risk of banking crises-revisited. (BIS Quarterly Review), pp. 29-46 (March).

Bouzouita, R. and A.J. Young (1998), ‘A Probit Analysis of Best Ratings', The Journal of Insurance Issues, Vol. 21, pp. 23-34.

Brotman, B.A., 1989. 'Reliability of Best's Insurer Ratings Using Financial Information Published in the Annual Report', Journal of Insurance Issues and Practices, Vol. 12, pp. 5870.

Carmichael, J., Pomerleano, M., 2002. The Development and Regulation of Non-Bank Financial Institutions. World Bank, Washington.

Carson, J.M. andW.L. Scott, 1997. 'Life Insurers and the 'Run on the Insurer' Exposure', Journal of the American Society of CLU \& ChFC, pp. 44-48.

C.-C. Lee, C.-W. Lin, J.-H. Zeng, 2016. Financial liberalization, insurance market, and the likelihood of financial crises, Journal of International Money and Finance 62 (2016) 25-51. 
D. Rule, 2001. Risk Transfer between Banks. Insurance Companies and Capital Markets: An Overview. Bank of England, pp. 137-159

Das U.S., N. Davies, R. Podpiera, 2003. Insurance and Issues in Financial Soundness, IMF Working Paper WP/03/138.

Das, S., Due, D., Kapadia, N. and Saita, L. (2007). Common failings: how corporate defaults are correlated. Journal of Finance 62(1), 93-117.

Demirgüç-Kunt, A., Detragiache, E., 1998.The determinants of banking crises in developed and developing countries. IMF Staff. Pap. 45, 81-109.

Doherty, N.A., Tinic, S.M., 1981. Reinsurance under conditions of capital market equilibrium: a note. Journal of Finance 36, 949-953.

Drehmann, M., Juselius, M., 2014.Evaluating early warning indicators of banking crises: satisfying policy requirements. International Journal of Forecasting. 30 (3), 759-780.

Duan J.C., Sun J. and T. Wang, 2012. Multiperiod Corporate Default Prediction - A Forward Intensity Approach. Journal of Econometrics 170, 191-209.

Duffie D. and Kenneth J. Singleton, 1999. Modeling the Term Structures of Defaultable Bonds. Review of Financial Studies, 12(4), pp.687-720.

Duffie D., Saita L. and Wang K., 2007. Multi-period corporate default prediction with stochastic covariates. Journal of Financial Economics. 83, 635-665.

Faure, M., Heine, K., 2011. Insurance against financial crises? New York Univ. J. Law Bus. 8, 117-150.

F. Baluch, S. Mutenga, C. Parsons, 2011. Insurance, systemic risk and the financial crisis. Geneva Papers on Risk and Insurance. 36, pp. 126-163.

Frank, M. Z., and V. K. Goyal, 2009. Capital Structure Decisions: Which Factors Are Reliably Important? Financial Management, Spring: 1-37.

Geneva Association, 2010. Systemic Risk in Insurance - An Analysis of Insurance and Financial Stability, Special Report of The Geneva Association Systemic Risk Working Group.

Harrington, S.E., Niehaus, G., 2003. Capital, corporate income taxes, and catastrophe insurance. Journal of Financial Intermediation 12, 365-389.

Harrington S.E., 2009. The financial crisis, systemic risk, and the future of insurance regulation. Journal of Risk Insurance., 76 pp. 785-819.

Harris, M., Raviv, A., 1991. The theory of capital structure. Journal of Finance 46, 297-355.

Hillegeist S., E. Keating, D. Cram and K. Lundstedt, 2004. Assessing the probability of bankruptcy. Review of Accounting Studies, vol. 9, pp. 5-34.

IAIS, 2003. Credit risk transfer between insurance, baking, and other financial sectors. March.

Kaminsky, G.L., Reinhart, C.M., 1999.The Twin Crises: The Causes of Banking and Balance-of-Payments Problems. The American Economic Review. 89, 473-500.

Kugler, M., Ofoghi, R., 2005. Does insurance promote economic growth? Evidence from the UK. Working paper (May 2005), Division of Economics, University of Southampton, UK 
Lee, C.C., 2013. Insurance and real output: The key role of banking activities. Macroeconomic Dynamics 17, 235-260. Cambridge University Press.

Lee, C.C., Chang, C.H., 2015. Financial policy and insurance development: Do financial reforms matter and how? International Review of Economics \& Finance. 38 (C), 258-278.

International Association of Insurance Supervisors (IAIS), 2011. Insurance and Financial Stability. IAIS, Basel.

International Underwriting Association, 2015. London Company Market Statistics Report 2015. IUA, London.

Janina Mühlnickel and Gregor N.F. Weiß, 2015. Consolidation and systemic risk in the international insurance industry. Journal of Financial Stability. Vol.18, pp. 187-202.

Jarrow Robert A. and Stuart M. Turnbull, 1995. Pricing Derivatives on Financial Securities Subject to Credit Risk. Journal of Finance, 50(1), pp. 53-85.

Lehmann, A.P., Hofmann, D.M., 2010. Lessons learned from the financial crisis for risk management: Contrasting developments in insurance and banking. Geneva Papers on Risk and Insurance-issues and Practice. 35, 63-78.

Lloyd's of London, 2014. Lloyd's 2014 Annual Report. Lloyd's, London.

Main, B.G.M., 1982. Business insurance and large, widely-held corporations. The Geneva Papers on Risk and Insurance. 7 (24), 237-247.

Merton, Robert C., 1974. On the Pricing of Corporate Debt: The Risk Structure of Interest Rates. Journal of Finance, 29(2), pp. 449-470.

Pottier, S.W., 1997. 'Life Insurer Risk Characteristics and the Rating Process', The Journal of Insurance Issues, Vol. 20, pp. 111-30.

Pottier, S.W., 1998. 'Life Insurer Financial Distress, Best's Ratings and Financial Ratios', The Journal of Risk and Insurance, Vol. 65, pp. 275-88.

R. Schmidt, U. Stadtmüller, 2006. Nonparametric estimation of tail dependence. Scandinavian Journal of Statistics., 33, pp. 307-335

Rothstein, J., 2011. Unemployment insurance and job search in the Great Recession. Working paper.

Schularick, M., Taylor, A.M., 2012.Credit booms gone bust: monetary policy, leverage cycles and financial crises 1870-2008. The American Economic Review. 102, 1029-1061.

Shiu Yung-Ming, 2007. An empirical investigation on derivatives usage: evidence from the United Kingdom general insurance industry. Applied Economics Letters, 14:5, 353-360.

Shiu Yung-Ming, 2011. Reinsurance and Capital Structure: Evidence from the United Kingdom Non-Life Insurance Industry. The Journal of Risk and Insurance, 2011, Vol. 78, No. 2, 475-494

Titman, S., and R.Wessels, 1988, TheDeterminants of Capital StructureChoice, Journal of Finance, 43: 1-19.

Trichet, J.C., 2005. Financial stability and the insurance sector. The Geneva Papers on Risk and Insurance - Issues and Practices 30, 65-71.

Ward, D., Zurbruegg, R., 2000. Does insurance promote economic growth? Evidence from OECD countries. Journal of Risk and Insurance. 67 (4),489-506. 


\section{Appendix A - Insolvency cases}

AA Mutual Intl Ins

Andrew Weir Ins

Anglo American

Atlantic Mutual Intl

BAI (Run-Off)

BlackSea\&Baltic

Bryanston Ins

Chester St Emp

City Intl Ins

Drake Ins

Exchange Ins

FolksamIntl UK

Highlands Ins UK

HIH Cas\&Gen Ins

Independent Ins

Island Cap Europe

London Auths Mut

Millburn Ins

Municipal General

North Atlantic Ins

OIC Run-Off

Paramount Ins

Scan RE

SovereignMar\&Gen

UIC Ins 
Baloise Ins Ukbr

East West Ins

Fuji Intl Ins

Hiscox Ins

Metropolitan RE

Moorgate Ins

Nippon InsCo Europe

Polygon Ins UK

Swiss RE (UK)

Tower Ins Ukbr 


\section{Appendix B - Multi-period Default Estimation Outputs}

\begin{tabular}{|c|c|c|c|c|c|}
\hline & 1 & 2 & 3 & 4 & 5 \\
\hline \multirow[t]{2}{*}{$\mathrm{C}$} & $-26.959 * * *$ & -37.507 & -36.182 & -49.547 & -18.585 \\
\hline & -8.411 & -125.922 & -61.624 & -110.445 & -93.697 \\
\hline \multirow[t]{2}{*}{ GDP_growth } & -0.013 & 0.045 & 0.079 & 0.449 & 0.015 \\
\hline & -0.098 & -0.87 & -0.373 & -0.694 & -0.432 \\
\hline \multirow[t]{2}{*}{ Real_IR } & $0.109 * *$ & 0.217 & 0.152 & 0.265 & 0.189 \\
\hline & -0.043 & -0.422 & -0.322 & -0.77 & -0.598 \\
\hline \multirow[t]{2}{*}{ Real_EXrate } & 0.007 & 0.011 & 0.004 & 0.019 & -0.003 \\
\hline & -0.013 & -0.275 & -0.145 & -0.238 & -0.22 \\
\hline \multirow[t]{2}{*}{ FDI \% } & -0.073 & 0.022 & -0.148 & -0.095 & -0.022 \\
\hline & -0.072 & -0.865 & -0.546 & -0.566 & -0.183 \\
\hline \multirow[t]{2}{*}{ Wholesale Price \% } & $22.777 * * *$ & 25.717 & 24.151 & 38.491 & 6.943 \\
\hline & -7.452 & -95.525 & -49.076 & -88.161 & -77.494 \\
\hline \multirow[t]{2}{*}{ Credit by Financial \% } & $-4.323^{* * *}$ & -0.286 & 0.584 & -2.292 & $4.415^{* * *}$ \\
\hline & -1.586 & -1.295 & -0.878 & -1.739 & -0.801 \\
\hline \multirow[t]{2}{*}{ PT } & $-4.895 * * *$ & -3.455 & 1.09 & 1.096 & 3.884 \\
\hline & -1.284 & -38.286 & -34.568 & -53.766 & -66.484 \\
\hline \multirow[t]{2}{*}{ Lev } & $1.972 * * *$ & 2.134 & 1.857 & 1.585 & 2.288 \\
\hline & -0.323 & -5.682 & -4.868 & -7.259 & -9.352 \\
\hline \multirow[t]{2}{*}{ Size } & 0.022 & 0.127 & 0.12 & 0.062 & -0.146 \\
\hline & -0.062 & -0.607 & -0.31 & -0.41 & -0.472 \\
\hline \multirow[t]{2}{*}{ CA } & -0.21 & 0.21 & -0.001 & -2.414 & -2.698 \\
\hline & -0.562 & -0.757 & -1.692 & -5.414 & -1.921 \\
\hline \multirow[t]{2}{*}{ GPW\% } & $-0.414 * * *$ & -0.143 & 0.098 & -0.164 & 0.016 \\
\hline & -0.111 & -0.506 & -0.28 & -0.456 & -0.432 \\
\hline \multirow[t]{2}{*}{ Rein } & $1.123^{* * *}$ & 1.898 & 2.034 & 1.783 & 1.078 \\
\hline & -0.304 & -9.542 & -6.758 & -9.141 & -8.315 \\
\hline \multirow[t]{2}{*}{ Claim\% } & $0.052 * * *$ & -0.012 & -0.003 & 0.04 & 0.047 \\
\hline & -0.015 & -0.331 & -0.079 & -0.217 & -0.164 \\
\hline \multirow[t]{2}{*}{ Growth } & 0.059 & 0.111 & 0.283 & 0.187 & 0.251 \\
\hline & -0.118 & -1.817 & -1.759 & -2.643 & -2.181 \\
\hline \multirow[t]{2}{*}{ Eecess\% } & $-0.229 *$ & -0.261 & -0.187 & 0.027 & -0.101 \\
\hline & -0.123 & -0.671 & -0.356 & -0.471 & -0.598 \\
\hline \multirow[t]{2}{*}{ InvR } & $-24.849 * * *$ & -14.78 & -4.048 & -9.868 & -3.836 \\
\hline & -7.364 & -301.181 & -205.288 & -303.345 & -303.642 \\
\hline \multirow[t]{2}{*}{ Combined Ratio } & $0.026^{* * *}$ & 0.013 & 0.025 & 0.017 & 0.065 \\
\hline & -0.01 & -0.092 & -0.036 & -0.148 & -0.049 \\
\hline \multirow[t]{2}{*}{ Herfindahl index } & 0.429 & 1.021 & $1.683^{*}$ & 1.994 & 1.512 \\
\hline & -0.377 & -2.248 & -0.978 & -2.022 & -1.518 \\
\hline \multirow[t]{2}{*}{ Derivative Dummy } & $0.654^{* *}$ & 0.298 & 0.521 & 0.528 & 0.967 \\
\hline & -0.275 & -0.757 & -0.39 & -0.359 & -0.779 \\
\hline Organizational Form & $0.642 * *$ & 0.604 & 0.577 & 0.225 & 0.07 \\
\hline
\end{tabular}


$-0.303$

$-2.535$

$-1.484$

$-1.723$

$-1.926$

Multi-period default estimation outputs in 1,2,3,4 and 5 years' time horizon.

\section{Appendix C - Multi-period Other Exit Estimation Outputs}

\begin{tabular}{|c|c|c|c|c|c|}
\hline & 1 & 2 & 3 & 4 & 5 \\
\hline \multirow[t]{2}{*}{$\mathrm{C}$} & -2.25 & -5.996 & -3.812 & -10.554 & -6.543 \\
\hline & -29.285 & -29.742 & -18.084 & -22.116 & -29.397 \\
\hline \multirow[t]{2}{*}{ GDP_growth } & -0.046 & -0.017 & 0.01 & 0.073 & 0.046 \\
\hline & -0.093 & -0.045 & -0.053 & -0.054 & -0.074 \\
\hline \multirow[t]{2}{*}{ Real_IR } & -0.01 & 0.049 & 0.048 & 0.011 & -0.024 \\
\hline & -0.242 & -0.261 & -0.17 & -0.216 & -0.295 \\
\hline \multirow{2}{*}{ Real_EXrate } & 0.014 & 0.005 & 0.002 & 0.003 & 0.009 \\
\hline & -0.061 & -0.058 & -0.032 & -0.039 & -0.048 \\
\hline \multirow[t]{2}{*}{ FDI \% } & 0.002 & 0.011 & -0.053 & -0.191 & 0.006 \\
\hline & -0.132 & -0.092 & -0.109 & -0.22 & -0.092 \\
\hline \multirow[t]{2}{*}{ Wholesale Price \% } & -4.248 & -0.067 & -2.454 & 5.55 & 3.514 \\
\hline & -23.218 & -23.994 & -14.397 & -17.451 & -26.661 \\
\hline \multirow{2}{*}{$\begin{array}{l}\text { Credit by } \\
\text { Financial \% }\end{array}$} & -0.535 & -1.482 & -1.109 & -3.343 & $-6.793 * * *$ \\
\hline & -1.131 & -1.07 & -1.495 & -2.921 & -2.103 \\
\hline \multirow[t]{2}{*}{ PT } & -2.119 & -0.118 & -1.599 & -2.416 & -2.672 \\
\hline & -14.92 & -16.619 & -10.447 & -14.4 & -15.724 \\
\hline \multirow[t]{2}{*}{ Lev } & 0.456 & 0.41 & 0.126 & -0.095 & -0.697 \\
\hline & -2.591 & -2.863 & -1.83 & -2.345 & -2.58 \\
\hline \multirow[t]{2}{*}{ Size } & -0.002 & 0.09 & 0.154 & 0.246 & 0.343 \\
\hline & -0.272 & -0.288 & -0.182 & -0.216 & -0.225 \\
\hline \multirow[t]{2}{*}{ CA } & $-1.479 *$ & $-1.214 * *$ & $-0.859 * *$ & -0.372 & $-0.953^{*}$ \\
\hline & -0.769 & -0.521 & -0.372 & -0.414 & -0.566 \\
\hline \multirow[t]{2}{*}{ GPW\% } & -0.029 & 0 & -0.018 & 0.035 & 0.038 \\
\hline & -0.158 & -0.18 & -0.122 & -0.157 & -0.154 \\
\hline \multirow[t]{2}{*}{ Rein } & 0.56 & 0.718 & 0.655 & 0.622 & 0.744 \\
\hline & -2.674 & -3.045 & -2.04 & -2.925 & -4.098 \\
\hline \multirow[t]{2}{*}{ Claim\% } & 0.056 & $0.063 * * *$ & $0.043^{* * *}$ & $-0.088 * * *$ & $-0.114^{* *}$ \\
\hline & -0.037 & -0.022 & -0.01 & -0.03 & -0.047 \\
\hline \multirow[t]{2}{*}{ Growth } & -0.315 & -0.401 & -0.447 & -0.483 & -0.505 \\
\hline & -0.756 & -0.887 & -0.602 & -0.846 & -1.132 \\
\hline \multirow[t]{2}{*}{ Eecess \% } & -0.08 & -0.014 & -0.035 & -0.055 & -0.07 \\
\hline & -0.141 & -0.158 & -0.12 & -0.191 & -0.192 \\
\hline \multirow[t]{2}{*}{ InvR } & 7.119 & 5.56 & 2.541 & -0.625 & 7.667 \\
\hline & -120.96 & -126.475 & -82.1 & -112.554 & -134.414 \\
\hline \multirow[t]{2}{*}{ Combined Ratio } & $0.097 * * *$ & $0.096 * * *$ & $0.101 * * *$ & $0.104 * * *$ & $0.043^{* * *}$ \\
\hline & -0.009 & -0.01 & -0.009 & -0.006 & -0.008 \\
\hline \multirow[t]{2}{*}{ Herfindahl index } & $1.078 * *$ & $1.496 * * *$ & $1.237 * * *$ & $1.227 * * *$ & $1.342^{* * *}$ \\
\hline & -0.435 & -0.286 & -0.253 & -0.357 & -0.271 \\
\hline \multirow[t]{2}{*}{ Derivative Dummy } & $1.059 * *$ & 0.636 & 0.349 & 0.316 & 0.454 \\
\hline & -0.53 & -0.533 & -0.327 & -0.426 & -0.489 \\
\hline \multirow[t]{2}{*}{ Organizational Form } & -0.1 & -0.173 & -0.131 & -0.031 & -0.181 \\
\hline & -1.23 & -1.15 & -0.725 & -0.937 & -1.021 \\
\hline
\end{tabular}

Multi-period other exit estimation outputs in 1,2,3,4 and 5 years' time horizon. 


\section{Appendix C - Default Probability of GI Industry (Median)}
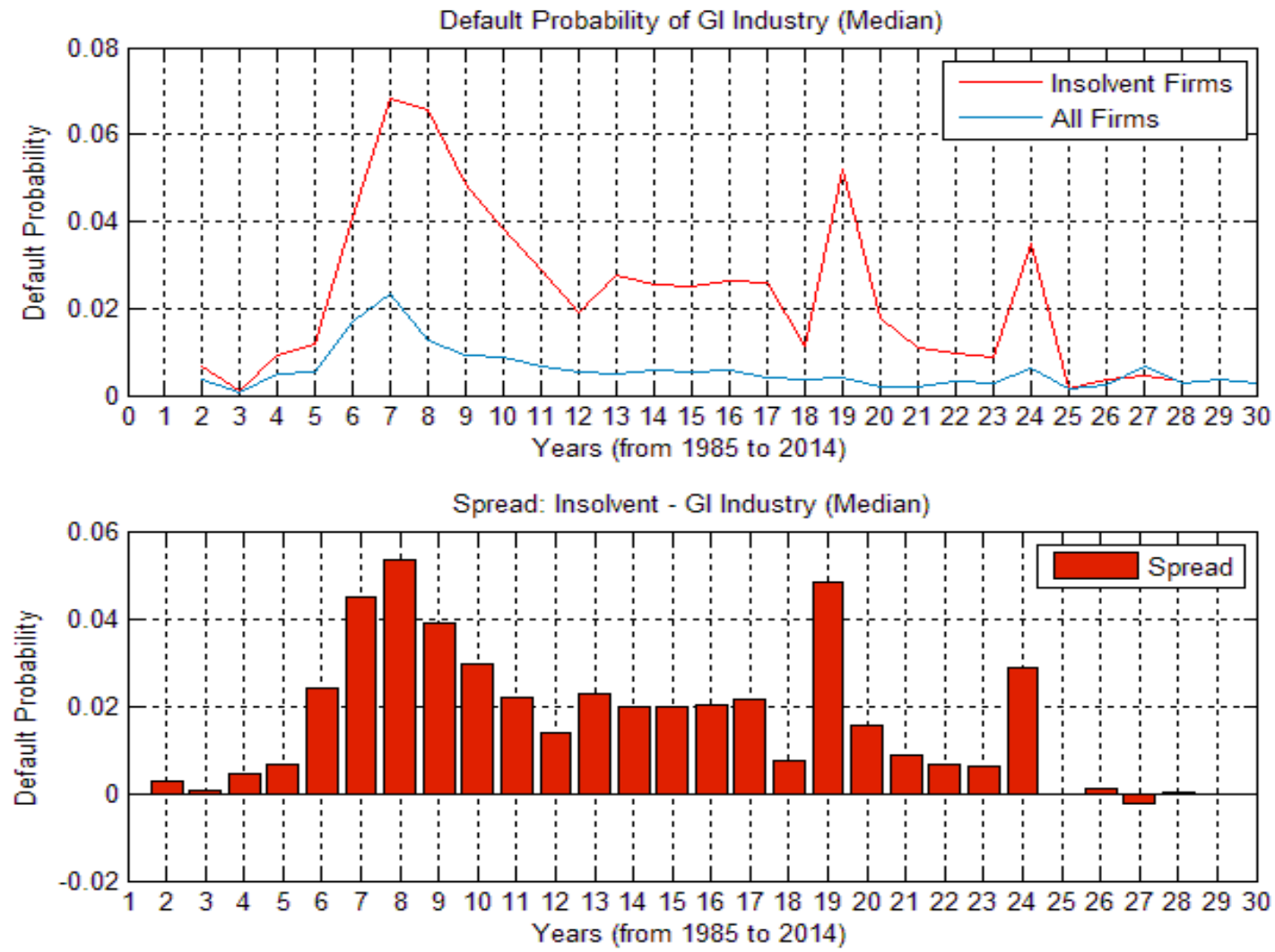